Historic, archived document

Do not assume content reflects current scientific knowledge, policies, or practices. 

OseIvod United States

Department of

Agriculture

Forest Service

Intermountain

Forest and Range

Experiment Station

Ogden, UT $\mathbf{8 4 4 0 1}$

Resource Bulletin

INT-32

August 1983

U:S
Forest Area and

Timber Resource

Statistics for State

and Private Lands in

New Mexico, 1980

Dorothy G Felt

Velma J. Sterrett 


\section{THE AUTHORS}

DOROTHY G. FELT, was a Supervisory Statistical Assistant (retired) with the Forest Survey Research Work Unit at the Intermountain Forest and Range Experiment Station in Ogden, Utah.

VELMA J. STERRETT is a Statistical Assistant with the Forest Survey Research Work Unit at the Intermountain Forest and Range Experiment Station in Ogden, Utah.

\section{ACKNOWLEDGMENTS}

The Intermountain Station gratefully acknowledges the cooperation of the New Mexico Division of State Forestry and State and Private Forestry, Forest Service, Southwestern Region. Appreciation is also expressed for the cooperation of other public agencies and private landowners in providing information and access to the sample locations.

\section{RESEARCH SUMMARY}

The State of New Mexico contains 1,254,958 acres of commercial timberland in State and private ownership. These acres support more than 1.1 billion cubic feet of growing stock and 4.1 billion board feet of sawtimber. Additional information on total land area, commercial timberland area, timber inventory, and net annual growth and mortality based on Forest Survey standards is presented. 


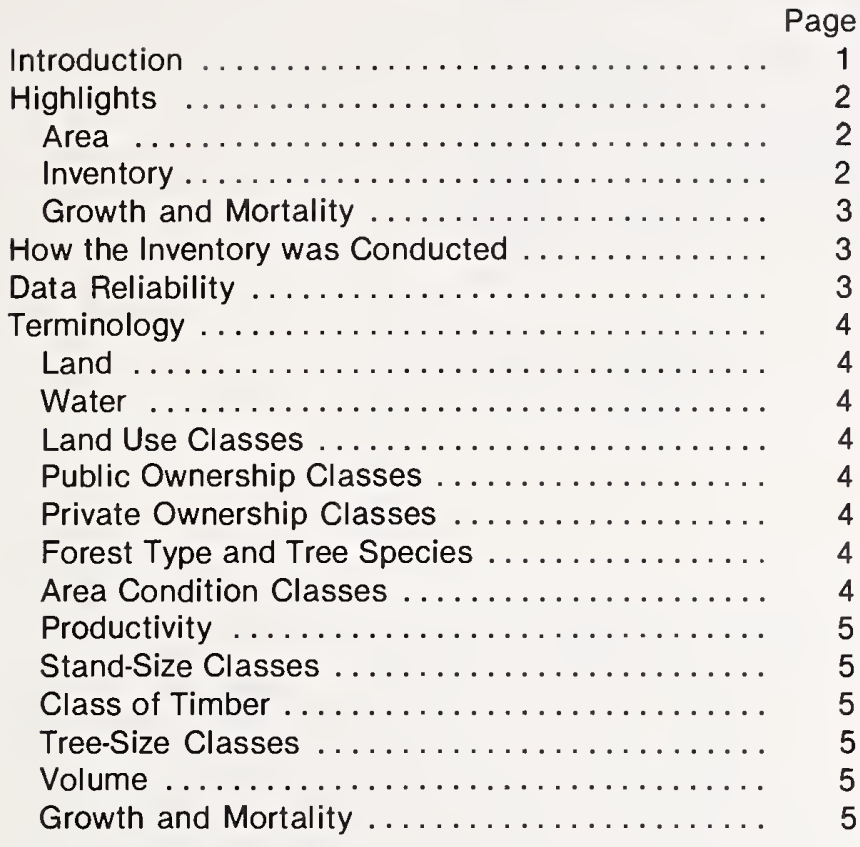

\section{FIGURES}

1. Date of inventory by working circle, New Mexico . . . . . . . . . . . . . . . . .

2. Percent of total land area in New Mexico by ownership, 1980 ..................

3. Percent of commercial timberland in New Mexico by forest type, 1980 . . . . . . . . . .

4. Percent of sound live tree volume in New Mexico by species, 1980 . . . . . . . . . .

\section{FOREST SURVEY TABLES}

1. Area of State and private forest land in New Mexico by type group, with percent standard error, 1980 ....................

2. Net volume, net annual growth, and annual mortality of growing stock and sawtimber on State and private commercial timberland in New Mexico by softwoods and hardwoods, with percent standard error ...........

3. Total land and water area in New Mexico by ownership class, 1980 . . . . . . . . . . .

4. Total land area of State and private ownership in New Mexico by major land class and ownership class, 1980

5. Area of State and private commercial timberland in New Mexico by forest type, stand-size class, and productivity class, 1980 . . . . . . . . . . . . . . . . . . . .

6. Area of State-owned commercial timberland in New Mexico by forest type, stand-size class, and productivity class, 1980 . . . . . .

7. Area of privately owned commercial timberland in New Mexico by forest type, stand-size class, and productivity class, 1980
8. Area of State and private commercial timberland in New Mexico by stand volume and ownership class, 1980 . . . . . . . . . .

9. Area of State and private commercial timberland in New Mexico by forest type and area condition class, 1980 .........

10. Area of State and private productive reserved and other forest land in New Mexico by land class, ownership class, and forest type, 1980 ... . . . . . . . . . . . . . .

11. Number of growing stock trees on State and private commercial timberland in New Mexico by species and diameter class, 1980

12. Number of cull and salvable dead trees on State and private commercial timberland in New Mexico by ownership class, and softwoods and hardwoods, 1980 . . . . . . . . .

13. Net volume of growing stock on State and private commercial timberland in New Mexico by ownership class, forest type, and stand-size class, 1980 . . . . . . . . .

14. Net volume of sawtimber on State and private commercial timberland in New Mexico by ownership class, forest type, and stand-size class, 1980. . . . . . . . . . . .

15. Net volume of growing stock on State and private commercial timberland in New Mexico by species and diameter class, 1980

16. Net volume of sawtimber on State and private commercial timberland in New Mexico by species and diameter class, 1980

17. Net volume of growing stock and sawtimber on State and private commercial timberland in New Mexico by ownership class and species, 1980 ...................

18. Net volume of timber on State and private commercial timberland in New Mexico by class of timber, and softwoods and hardwoods, 1980

19. Net volume of growing stock on State and private commercial timberland in New Mexico by forest type and species, 1980 ... .

20. Net volume of sawtimber on State and private commercial timberland in New Mexico by forest type and species, 1980 ....

21. Net annual growth of growing stock and sawtimber on State and private commercial timberland in New Mexico by ownership class and species, 1979 . . . . . . . . . .

22. Annual mortality of growing stock and sawtimber on State and private commercial timberland in New Mexico by ownership class, and softwoods and hardwoods, 1979 .

23. Annual mortality of growing stock and sawtimber on State and private commercial timberland in New Mexico by cause of death and species, $1979 \ldots \ldots \ldots \ldots \ldots$. . . . . 



\section{4 \\ g Forest Area and Timber Resource Statistics for State and Private Lands in New Mexico, 1980 [-4]. $\Longrightarrow$}

\section{Dorothy G/Felt}

Velma J. Sterrett

\section{INTRODUCTION}

This resource bulletin presents the principal findings of the second Statewide inventory of State and private lands in New Mexico. The first inventory, conducted in 1962, did not sample counties intensively nor were the findings reported at a county or working circle level. Fieldwork for the second cycle, conducted by personnel from the New Mexico Division of State Forestry and the Forest Survey Research Work Unit at the Intermountain Forest and Range Experiment Station in Ogden, Utah, began in 1970 and was completed in 1980 (fig. 1). To allow for meaningful comparisons the data for those working circles inventoried early in the cycle were updated to 1980. Thus, the information reported here will differ from totals obtained by adding the statistics contained in the individual working circle reports.

The primary objective of Forest Survey, a continuing nationwide undertaking conducted by the Forest Service, U.S. Department of Agriculture, is to provide an assessment of the renewable resource situation for forest and range lands of the Nation. Fundamental to the accomplishment of this objective are the periodic State-byState resource inventories. Originally, Forest Survey was

\section{NEW MEXICO}

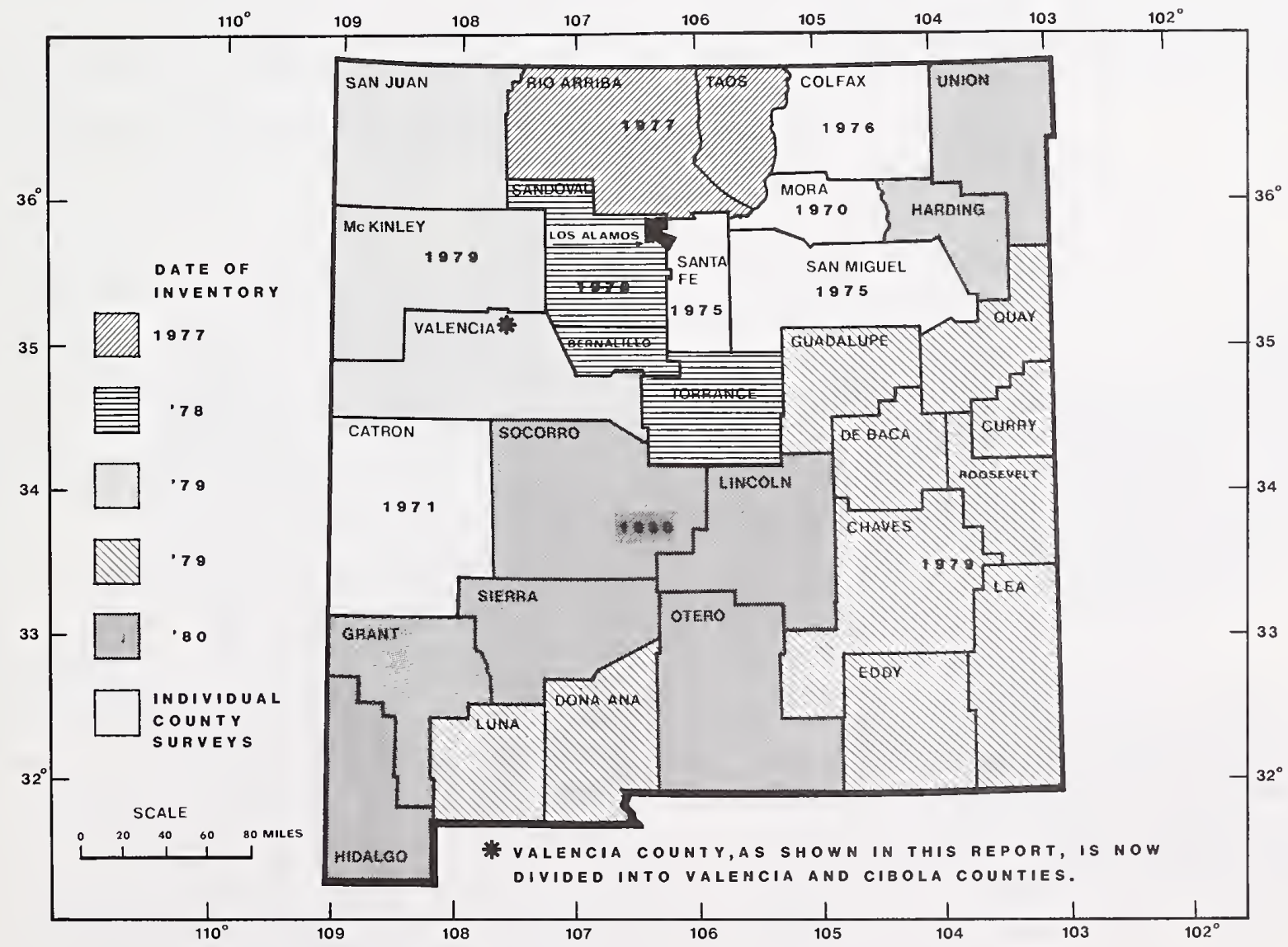

Figure 1.-Date of inventory by working circle, New Mexico. 
authorized by the McSweeney-McNary Act of 1928. The current authorization is through the Renewable Resources Research Act of 1978.

The resource inventories for the Rocky Mountain States of Arizona, Colorado, Idaho, Montana, New Mexico, Nevada, Utah, Wyoming, western South Dakota, west Texas, and Oklahoma's Panhandle are administered by the Intermountain Forest and Range Experiment Station with headquarters in Ogden, Utah. These inventories provide information on the extent and condition of State and privately owned forest lands, volume of timber, and rates of timber growth and mortality. These data, when combined with similar information on Federal lands, provide a basis for the formulation of forest policies and programs and for the orderly development and use of the resources.

\section{HIGHLIGHTS}

\section{Area}

- The forest land area is $6,998,934$ acres or 15 percent of the total State and private land area in New Mexico (fig. 2).

- Of the forest land, 1,254,958 acres, almost 18 percent, is classified as commercial timberland.

- Private ownership accounts for 1,161,972 acres, over 92 percent of the commercial timberland.

- $\quad$ Ponderosa pine, Douglas-fir, fir-spruce, and aspen are the predominant forest types and occupy 91 percent of the commercial timberland (fig. 3).

- Over 71 percent of the commercial timberland is in the 20 to 49 cubic foot productivity class, and 92 percent of this is privately owned.

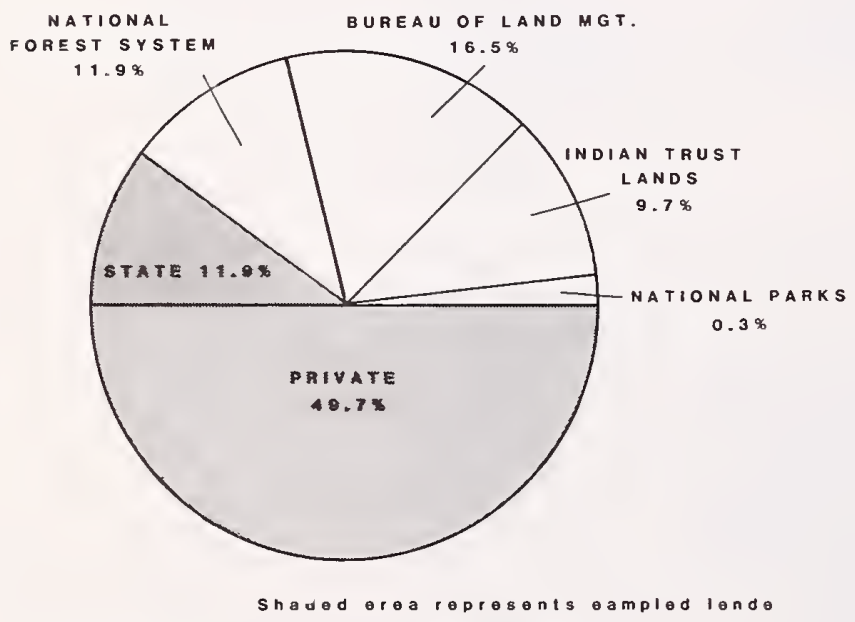

Figure 2.- Percent of total land area in New Mexico by ownership, 1980. (In this publication the private ownership category includes farmer-owned and other private ownerships, a small acreage of county and municipal ownerships and approximately 2.6 million acres of miscellaneous Federal ownership.)

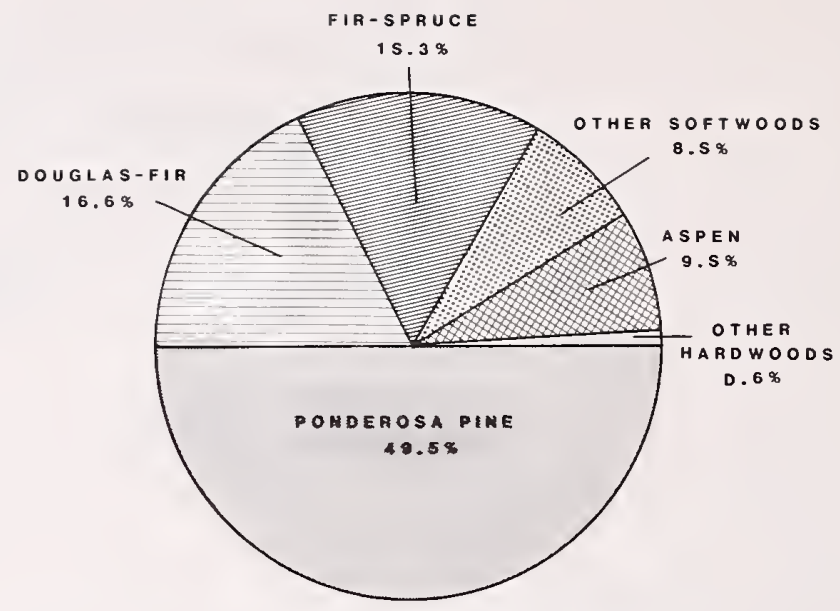

Figure 3.-Percent of commercial timberland in New Mexico by forest type, 1980.

\section{Inventory}

- Growing stock amounts to more than 1.1 billion cubic feet and sawtimber volume totals 4.1 billion board feet. In this report all reference to sawtimber volume is in International $1 / 4$-inch rule.

- Ponderosa pine is the predominate species on 50 percent of the commercial timberland (fig. 3).

- Rough, rotten, and salvable dead trees comprise over 101 million cubic feet, 8 percent of the total sound wood volume.

- More than two-thirds of the growing stock volume is in ponderosa pine, Engelmann spruce, and Douglasfir (fig. 4).

- Private owners control 93 percent of both the total growing stock and sawtimber volume.

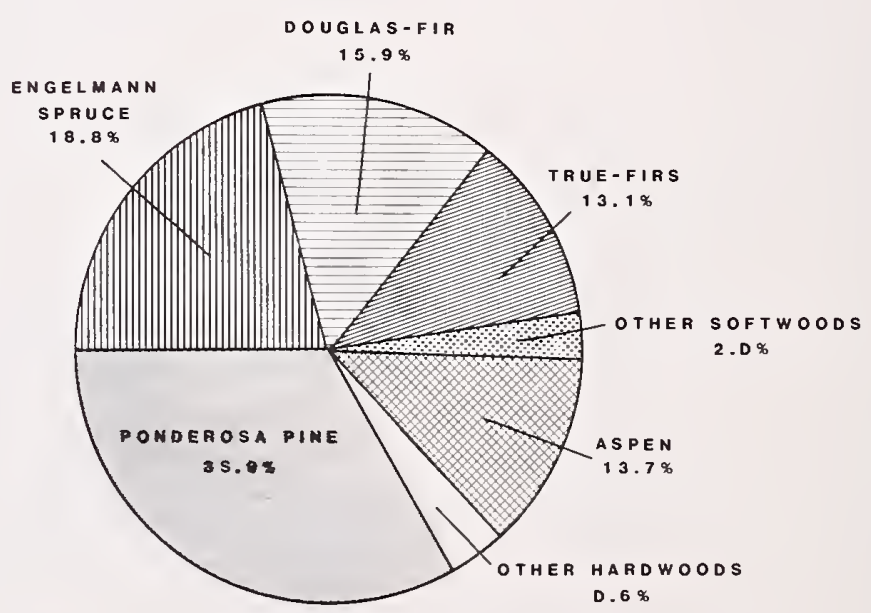

Figure 4.-Percent of sound live tree volume in New Mexico by species, 1980. 


\section{Growth and Mortality}

- Net annual growth of growing stock totals 27.9 million cubic feet and 118.2 million board feet.

- About 94 percent of the total net growth is on private lands.

- The annual mortality of 1.9 million cubic feet offsets 6 percent of the gross annual growth.

\section{HOW THE INVENTORY WAS CONDUCTED}

The inventory was designed to provide reliable statistics primarily at the State and working circle levels. Procedures were:

1. Initial area estimates were based on the classification of 336,171 sample points systematically placed on the latest aerial photographs available. The sample points were summarized and grouped into strata for subsequent field sampling. The photo points, adjusted to meet known land areas, were used to compute area expansion factors for the field stratum means.

2. Land classification and estimates of timber characteristics and volume were based on observations and measurements recorded at 1,709 ground sample locations of which 1,427 were forested. Sample trees were selected using a 10-point cluster, which includes fixed plots ( $1 / 300$ acre) for trees less than 5.0 inches diameter at breast height (d.b.h.) and variable plots ( 40 basal area factor) for trees 5.0 inches d.b.h. or larger.

3. Equations prepared from detailed measurements collected on trees throughout the Southwest were used to compute the volume and defect of individual tally trees.

4. All photo and field data were sent to Ogden, Utah, for editing and were punched onto cards and stored for machine computing, sorting, and tabulation. Final estimates were based on statistical summaries of the data.

\section{DATA RELIABILITY}

Individual cells within tables should be used with caution. Some are based on very small sample sizes, and so result in high sampling errors. The standard error percents shown in tables 1 and 2 were calculated at the 67 percent confidence level.

Table 1.--Area of State and private forest land in New Mexico by type group, with percent standard error, 1980

\begin{tabular}{|c|c|c|c|c|}
\hline Item & Softwood type & Hardwood type & A11 types & $\begin{array}{l}\text { Percent } \\
\text { standard } \\
\text { error }\end{array}$ \\
\hline & $----\cdots$ & $--\cdots A C$ & $-\cdots$ & $-\cdot-\cdot$ \\
\hline Commercial timberland & $1,127,304$ & 127,654 & $1,254,958$ & \pm 2.7 \\
\hline Productive reserved & 438 & 790 & 1,228 & \\
\hline $\begin{array}{l}\text { Other forest land: } \\
\text { Unproductive reserved } \\
\text { Unproductive nonreserved }\end{array}$ & $\begin{array}{r}37,906 \\
5,120,828 \\
\end{array}$ & $\begin{array}{r}4,885 \\
579,129 \\
\end{array}$ & $\begin{array}{r}42,791 \\
5,699,957 \\
\end{array}$ & \\
\hline
\end{tabular}

Table 2.--Net volume, net annual growth, and annual mortality of growing stock and sawtimber on State and private commercial timberland in New Mexico by softwoods and hardwoods, with percent standard error

\begin{tabular}{|c|c|c|c|c|}
\hline Item & Softwoods & Hardwoods & A11 species & $\begin{array}{l}\text { Percent } \\
\text { standard } \\
\text { error }\end{array}$ \\
\hline & ---- & ---- & Ime - - - - & $-\cdots-$ \\
\hline $\begin{array}{l}\text { Net volume, } 1980 \\
\text { Growing stock (M cubic feet) } \\
\text { Sawtimber (M board feet }{ }^{1} \text { ) }\end{array}$ & $\begin{array}{r}986,309 \\
3,807,205\end{array}$ & $\begin{array}{l}164,958 \\
334,754\end{array}$ & $\begin{array}{l}1,151,267 \\
4,141,959\end{array}$ & $\begin{array}{l} \pm 6.1 \\
\pm 4.5\end{array}$ \\
\hline $\begin{array}{l}\text { Net annual growth, } 1979 \\
\text { Growing stock (M cubic feet) } \\
\text { Sawtimber ( } M \text { board feet }{ }^{-1} \text { ) }\end{array}$ & $\begin{array}{r}23,473 \\
105,039\end{array}$ & $\begin{array}{r}4,476 \\
13,204\end{array}$ & $\begin{array}{r}27,949 \\
118,243\end{array}$ & $\begin{array}{l} \pm 4.4 \\
\pm 5.8\end{array}$ \\
\hline $\begin{array}{l}\text { Annual mortality, } 1979 \\
\text { Growing stock (M cubic feet) } \\
\text { Sawtimber ( } M \text { board feet }{ }^{1} \text { ) }\end{array}$ & $\begin{array}{l}1,570 \\
5,963 \\
\end{array}$ & $\begin{array}{l}294 \\
658 \\
\end{array}$ & $\begin{array}{l}1,864 \\
6,621 \\
\end{array}$ & $\begin{array}{l} \pm 19.6 \\
\pm 21.5 \\
\end{array}$ \\
\hline
\end{tabular}

\footnotetext{
${ }^{1}$ International 1/4-inch rule.
} 


\section{TERMINOLOGY}

The following section contains definitions that are relevant to the timber resource data presented in this resource bulletin.

\section{Land}

Area of dry land and land temporarily or partly covered by water, such as marshes, swamps, and river flood plains; streams, sloughs, estuaries, and canals less than 120 feet in width; and lakes, reservoirs, and ponds less than 1 acre in size.

\section{Water}

Streams, sloughs, estuaries, and canals more than 120 feet in width; and lakes, reservoirs, and ponds more than 1 acre in size.

\section{Land Use Classes}

Forest land.-Land at least 10.0 percent stocked by forest trees of any size, or formerly having had such tree cover, and not currently developed for nonforest use.

Commercial timberland.-Forest land producing or capable of producing crops of industrial wood and not withdrawn from timber utilization. (Areas qualifying have the capability of producing in excess of 20 cubic feet per acre per year of industrial wood in natural stands. Currently inaccessible and inoperable areas are included.)

Productive-reserved forest land.-Forest land sufficiently productive to qualify as commercial timberland, but withdrawn from timber utilization through statute, administrative designation, or exclusive use for Christmas tree production.

Other forest land.-Forest land incapable of producing 20 cubic feet per acre per year of industrial wood in natural stands because of adverse site conditions; includes both reserved and nonreserved forest land.

Nonforest land.-Land that has never supported forests and lands formerly forested where use for timber management is precluded by development for other uses.

\section{Public Ownership Classes}

National Forest lands. - Federal lands legally designated as National Forest or purchase units and other lands under the administration of the Forest Service, including experimental areas and Bankhead-Jones Title III lands.

Bureau of Land Management lands. - Federal lands administered by the Bureau of Land Management.

Miscellaneous Federal lands.-Federal lands other than (1) National Forest lands; (2) lands administered by the Bureau of Land Management; and (3) Indian trust lands.

Indian trust lands. - Indian lands held in trust by the Federal Government, for Indian tribal groups or for individual allotments.

State lands. - Lands owned by State or lands leased to the State for 50 years or more.
County and municipal lands. - Lands owned by counties and local public agencies or municipalities, or lands leased to these governmental units for 50 years or more.

\section{Private Ownership Classes}

Forest industry lands. - Lands owned by companies or by individuals operating wood-processing plants.

Farmer-owned lands. - Lands owned by farm operators. These exclude lands leased by farm operators from such nonfarm owners as railroad companies and States.

Other private lands. - Privately owned lands other than forest industry and farmer-owned lands.

\section{Forest Type and Tree Species}

Forest types. - A classification of forest land based upon the species forming a plurality of live-tree stocking.

Forest trees. - Woody plants having a well-developed stem and usually more than 12 feet in height at maturity.

Commercial species. - Tree species presently or prospectively suitable for industrial wood products.

Softwoods. - Monocotyledonous trees, usually evergreen having needles or scalelike leaves.

Hardwoods.-Dicotyledonous trees, usually broadleaved and deciduous.

\section{Area Condition Classes}

Stocking.-Stocking is an expression of the extent to which growing space is effectively utilized by present or potential growing stock trees of commercial species. "Percent of stocking" is synonymous with "percentage of growing space occupied" and means the ratio of actual stocking to full stocking for comparable sites and stands. Basal area is used as a basis for measuring stocking.

"Stocking percentages" express current area occupancy in relation to specified standards for full stocking based on number, size, and spacing of trees considered necessary to fully utilize the forest land.

Full utilization of the site is assumed to occur over a range of basal area. As an interim guide, 60 percent of normal yield table values has been used to establish the lower limit of this range, which represents full-site occupancy, and equals 100-percent stocking. The upper limit of full stocking has been set at 132 percent.

Class 10.-Areas fully stocked (100 to 132 percent) with desirable trees and not overstocked (133 percent or more).

Class 20-Areas fully stocked with desirable trees, but overstocked with all live trees.

Class 30.-Areas medium to fully stocked (60 to 99 percent) with desirable trees and with less than 30 percent of the area controlled by other trees and/or inhibiting vegetation or surface conditions that will prevent occupancy by desirable trees.

Class 40.-Areas medium to fully stocked with desirable trees and with 30 percent or more of the area controlled by other trees and/or conditions that ordinarily prevent occupancy by desirable trees.

Class 50.-Areas poorly stocked (16.7 to 59 percent) with desirable trees, but fully stocked with growing stock trees. 
Class 60.-Areas poorly stocked with desirable trees, but with medium to full stocking of growing stock trees.

Class 70.-Areas nonstocked (less than 16.7 percent) or poorly stocked with desirable trees, and poorly stocked with growing stock trees.

Class 80.- Low-risk old-growth stands.

Class 90.-High-risk old-growth stands.

Nonstocked.-Areas less than 16.7 percent stocked with growing stock trees.

\section{Productivity}

Productivity class. - A classification of forest land in terms of potential growth in cubic feet of fully stocked natural stands.

\section{Stand-Size Classes}

Sawtimber stands.-Stands at least 16.7 percent stocked with growing stock trees, with half or more of total stocking in sawtimber or poletimber trees, and with sawtimber stocking at least equal to poletimber stocking.

Poletimber stands.-Stands at least 16.7 percent stocked with growing stock trees in which half or more of this stocking is in poletimber and/or sawtimber trees, and with poletimber stocking exceeding that of sawtimber.

Sapling-seedling stands. - Stands at least 16.7 percent stocked with growing stock trees in which more than half of the stocking is saplings and/or seedlings.

Nonstocked land.-Commercial timberland less than 16.7 percent stocked with growing stock trees.

\section{Class of Timber}

Growing stock trees. - Live trees of commercial species qualifying as desirable or acceptable trees. (Excludes rough, rotten, and dead trees.)

Desirable trees. - Growing stock trees (1) having no serious defect in quality to limit present or prospective use for timber products; (2) of relatively high vigor; and (3) containing no pathogens that may result in death or serious deterioration before rotation age.

Acceptable trees.-Growing stock trees meeting specified standards of size and quality, but not qualifying as desirable trees.

Rough trees. - (1) Live trees that do not contain at least one 12-foot saw log or two noncontiguous saw logs, each 8 feet or longer, now or prospectively, and/or do not meet Rocky Mountain regional specifications for freedom from defect primarily because of roughness or poor form; and (2) all live trees of noncommercial species.

Rotten trees.-Live trees that do not contain at least one 12-foot saw log or two noncontiguous saw logs, each 8 feet or longer, now or prospectively, and/or do not meet Rocky Mountain regional specifications for freedom from defect primarily because of rot; that is, when more than 50 percent of the cull volume (cubic-foot basis) in a tree is rotten.
Salvable dead trees. - Standing or down dead trees that are considered merchantable by Rocky Mountain regional standards.

Saw-log portion. - That part of the bole of sawtimber trees between the stump and the saw-log top. A 1-foot stump is used.

Upper-stem portion. - That part of the bole of sawtimber trees above the saw-log top to a minimum top diameter of 4.0 inches outside bark or to the point where the central stem breaks into limbs, whichever occurs first.

\section{Tree-Size Classes}

Seedlings. - Live trees less than 1.0 inch d.b.h. Saplings. - Trees 1.0 to 4.9 inches d.b.h.

Poletimber trees. - Trees at least 5.0 inches d.b.h., but smaller than sawtimber size.

Sawtimber trees. - Trees exceeding poletimber size. In the Intermountain States, the minimum d.b.h. for softwood sawtimber is 9.0 inches and for hardwoods 11.0 inches.

\section{Volume}

Cull volume.-Portions of a tree's volume that are not usable for industrial wood products because of rot, poor form, or other defect.

Net volume.-Gross volume less deductions for cull.

Growing stock volume.-Net volume in cubic feet of live sawtimber trees and live poletimber trees from stump to a minimum 4.0-inch top (of central stem) outside bark. Net volume equals gross volume less deduction for rot and missing bole sections.

Sawtimber volume. - Net volume in board feet of sawtimber trees of commercial species. Net volume equals gross volume less deduction for rot, sweep, crook, and other defects that affect use for lumber.

\section{Growth and Mortality}

Net annual growth.-The increase in net growing stock or sawtimber volume of a specified size class for a specific year. (Components of net annual growth include the increment in net volume of trees at the beginning of the specific year surviving to its end, plus the net volume of trees reaching the size class during the year, minus the net volume of trees that died during the year, minus the net volume of trees that became rough or rotten trees during the year.)

Mortality. - Number or sound-wood volume of growing stock trees dying from natural causes during a specified period, usually annually. 
Table 3.--Total land and water area in New Mexico by ownership class, 1980

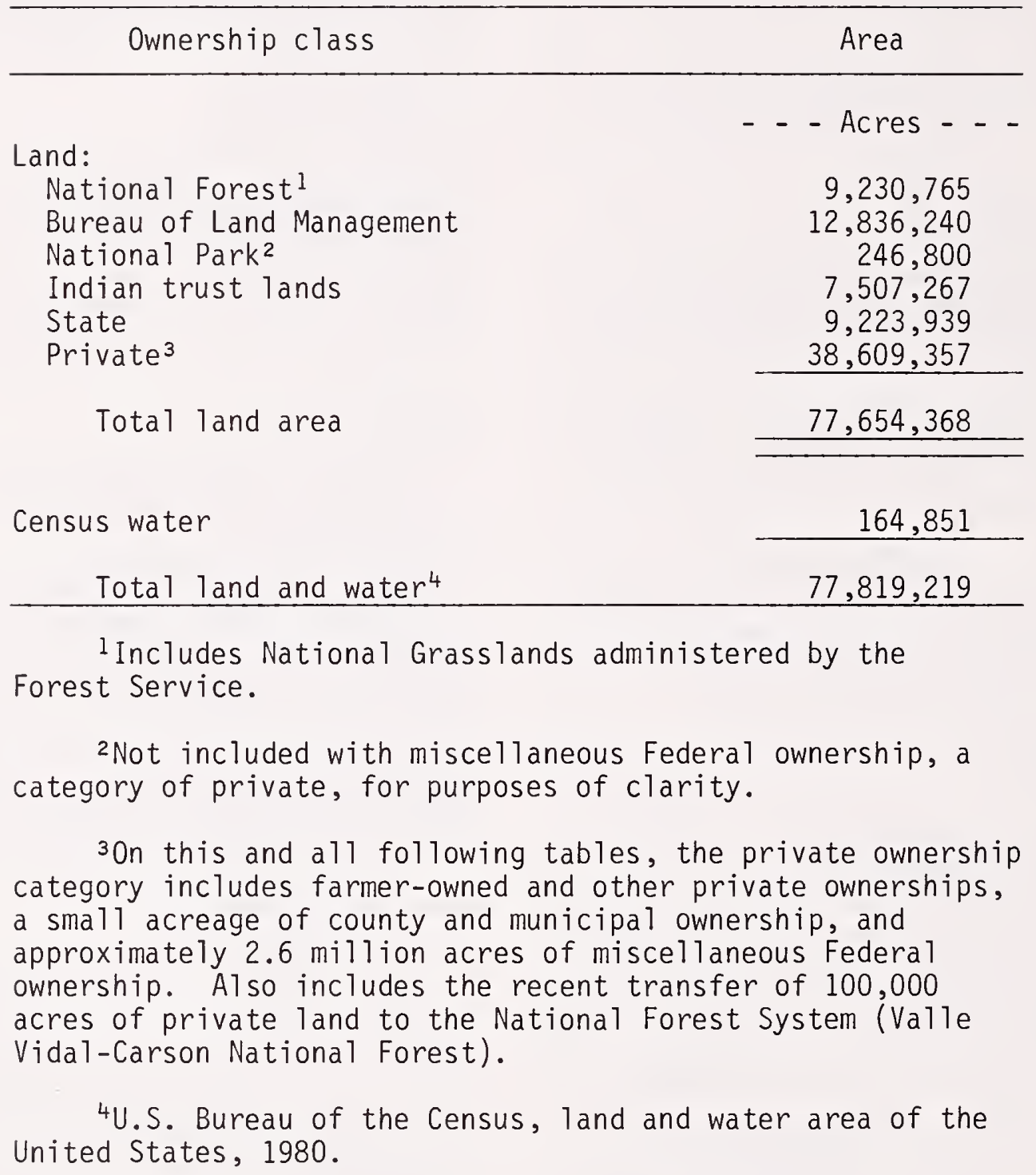


Table 4.--Total land area of State and private ownership in New Mexico by major land class and ownership class, 1980

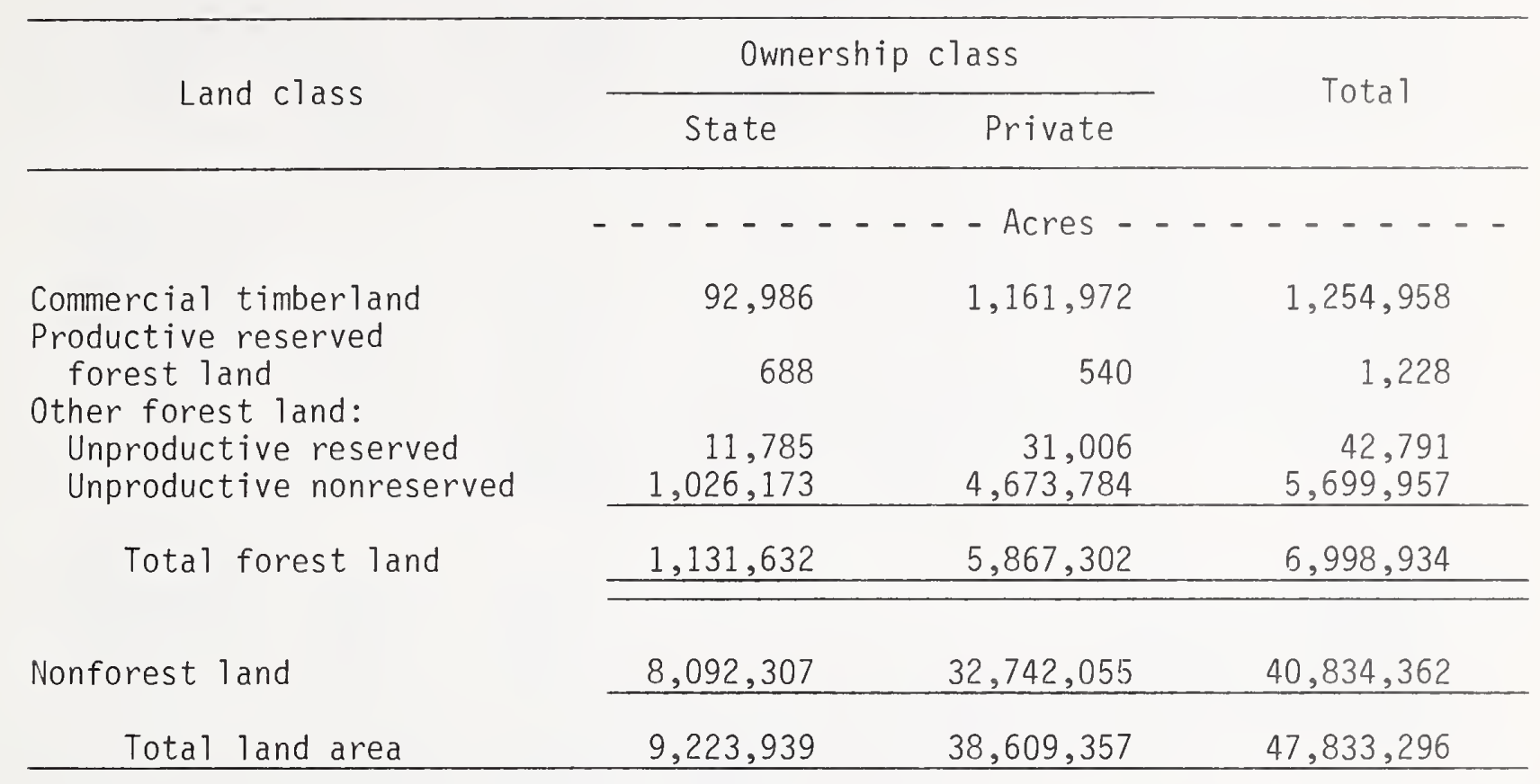


Table 5.--Area of State and private commercial timberland in New Mexico by forest type, stand-size class, and productivity class, 1980

Forest type and

stand-size class

\begin{tabular}{|c|c|c|c|}
\hline \multicolumn{4}{|c|}{ Productivity class } \\
\hline $120+$ & $85-119$ & $50-84$ & $20-49$ \\
\hline
\end{tabular}

$\ldots \ldots$. . . . . . Acres _..........

Douglas-fir:

Sawtimber

Poletimber

Sapling and seedling

Nonstocked

Total

\begin{tabular}{rrrrr}
-- & 5,177 & 39,094 & 87,217 & 131,488 \\
-- & -- & 10,051 & 37,529 & 47,580 \\
-- & -- & 3,125 & 23,285 & 26,410 \\
-- & -- & -- & 1,971 & 1,971 \\
\hline-- & 5,177 & 52,270 & 150,002 & 207,449 \\
\hline
\end{tabular}

Ponderosa pine:

Sawtimber

Poletimber

Sapling and seedling

Nonstocked

Total

Southwestern white pine:

Sawt imber

Poletimber

Sapling and seedling

Nonstocked

Total

Spruce-subalpine fir:

Sawtimber

Poletimber

Sapling and seedling

Nonstocked

Total

Limber pine:

Sawtimber

Poletimber

Sapling and seedling

Nonstocked

Total

White fir:

Sawtimber

Poletimber

Sapling and seedling

Nons tocked

Total

\begin{tabular}{rrrrr}
-- & 2,801 & 76,296 & 396,979 & 476,076 \\
-- & -- & 10,238 & 75,631 & 85,869 \\
-- & -- & 2,283 & 13,710 & 15,993 \\
-- & -- & -- & 43,210 & 43,210 \\
\hline-- & 2,801 & 88,817 & 529,530 & 621,148 \\
\hline
\end{tabular}

\begin{tabular}{ccccc}
-- & -- & 670 & -- & 670 \\
-- & -- & -- & -- & -- \\
-- & -- & -- & -- & -- \\
-- & -- & -- & -- & -- \\
\hline-- & -- & 670 & -- & 670 \\
\hline
\end{tabular}

\begin{tabular}{rrrrr}
-- & 5,575 & 55,947 & 40,839 & 102,361 \\
-- & -- & 10,327 & 9,644 & 19,971 \\
-- & 1,806 & -- & 9,877 & 11,683 \\
-- & -- & -- & -- & -- \\
\hline-- & 7,381 & 66,274 & 60,360 & 134,015 \\
\hline
\end{tabular}

\begin{tabular}{rrrrr}
2,643 & -- & 1,155 & -- & 3,798 \\
-- & -- & -- & -- & -- \\
-- & -- & -- & -- & -- \\
-- & -- & -- & -- & -- \\
\hline 2,643 & -- & 1,155 & -- & 3,798 \\
\hline & \multicolumn{7}{c}{} \\
-- & 4,676 & 23,376 & 15,904 & 43,956 \\
-- & -- & 644 & -- & 644 \\
-- & -- & -- & 3,510 & 3,510 \\
-- & -- & 613 & 1,970 & 2,583 \\
\hline-- & 4,676 & 24,633 & 21,384 & 50,693 \\
\hline
\end{tabular}

(con.) 
Table 5. (con.)

Forest type and

stand-size class

\begin{tabular}{llll}
\multicolumn{3}{c}{ Productivity class } & $\begin{array}{r}\text { Tota } \\
\text { acres }\end{array}$
\end{tabular}

Engelmann spruce:

Sawtimber

Poletimber

Sapling and seedling

Nons tocked

Total

Pinyon-juniper:

Sawtimber

Poletimber

Sapling and seedling

Nons tocked

Tota 1

Aspen:

Sawtimber

Poletimber

Sapling and seedling

Nonstocked

Total

Cottonwood:

Sawtimber

Poletimber

Sapling and seedling

Nons tocked

Total

Mixed hardwoods:

Sawtimber

Poletimber

Sapling and seedling Nons tocked

Tota 1

A11 types:

Sawtimber

Poletimber

Sapling and seedling

Nons tocked

\begin{tabular}{rrrrr}
-- & 7,167 & 10,341 & 10,031 & 27,539 \\
-- & 670 & 4,713 & 15,482 & 20,865 \\
-- & -- & 7,217 & 1,929 & 9,146 \\
-- & -- & -- & 662 & 662 \\
\hline-- & 7,837 & 22,271 & 28,104 & 58,212 \\
\hline
\end{tabular}

\begin{tabular}{rrrrr}
-- & -- & 123 & 22,193 & 22,316 \\
-- & -- & -- & 10,353 & 10,353 \\
-- & -- & -- & 9,396 & 9,396 \\
-- & -- & -- & 9,254 & 9,254 \\
\hline-- & -- & 123 & 51,196 & 51,319 \\
\hline
\end{tabular}

\begin{tabular}{rrrrr}
-- & 2,824 & 40,401 & 13,119 & 56,344 \\
611 & 5,509 & 8,878 & 8,515 & 23,513 \\
-- & -- & 9,666 & 30,143 & 39,809 \\
-- & -- & -- & -- & -- \\
\hline & & & & \\
611 & 8,333 & 58,945 & 51,777 & 119,666 \\
\hline
\end{tabular}

\begin{tabular}{rrrrr}
-- & 1,631 & -- & 2,982 & 4,613 \\
-- & -- & 1,882 & 729 & 2,611 \\
-- & -- & -- & -- & -- \\
-- & -- & -- & 661 & 661 \\
\hline-- & 1,631 & 1,882 & 4,372 & 7,885 \\
\hline
\end{tabular}

Total

\begin{tabular}{ccccc}
-- & -- & -- & 103 & 103 \\
-- & -- & -- & -- & -- \\
-- & -- & -- & -- & -- \\
-- & -- & -- & -- & -- \\
\hline-- & -- & -- & 103 & 103 \\
\hline
\end{tabular}

\begin{tabular}{rrrrr}
2,643 & 29,851 & 247,403 & 589,367 & 869,264 \\
611 & 6,179 & 46,733 & 157,883 & 211,406 \\
-- & 1,806 & 22,291 & 91,850 & 115,947 \\
-- & -- & 613 & 57,728 & 58,341 \\
\hline 3,254 & 37,836 & 317,040 & 896,828 & $1,254,958$ \\
\hline
\end{tabular}


Table 6.--Area of State-owned commercial timberland in New Mexico by forest type, standsize class, and productivity class, 1980

Forest type and stand-size class

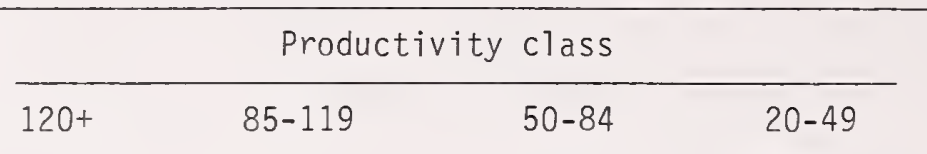

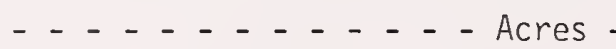

Douglas-fir:

Sawtimber

Poletimber

Sapling and seedling

Nonstocked

\section{Tota]}

Ponderosa pine:

Sawtimber

Poletimber

Sapling and seedling

Nonstocked

Tota]

Southwestern white pine:

Sawtimber

Poletimber

Sapling and seedling

Nonstocked

Tota $]$

Spruce-subalpine fir:

Sawtimber

Poletimber

Sapling and seedling

Nonstocked

Tota 1

Limber pine:

Sawtimber

Poletimber

Sapling and seedling Nonstocked

Tota]

White fir:

Sawtimber

Poletimber

Sapling and seedling

Nons tocked

Tota 1

\begin{tabular}{rrrrr}
-- & 55 & 2,059 & 3,840 & 5,954 \\
-- & -- & 1,398 & 4,642 & 6,040 \\
-- & -- & 261 & 3,159 & 3,420 \\
-- & 55 & 3,718 & 11,876 & 15,649 \\
\hline- & & & & \\
\hline & & & & \\
\hline-- & 307 & 4,922 & 29,718 & 34,947 \\
-- & -- & 687 & 5,931 & 6,618 \\
-- & -- & 19 & 1,058 & 1,077 \\
-- & -- & -- & 3,411 & 3,411 \\
\hline-- & 307 & 5,628 & 40,118 & 46,053 \\
\hline
\end{tabular}

Total

acres

\begin{tabular}{lllll}
-- & -- & 6 & -- & 6 \\
-- & -- & -- & -- & -- \\
-- & -- & -- & -- & -- \\
-- & -- & -- & -- & -- \\
\hline-- & -- & 6 & - & 6 \\
\hline
\end{tabular}

\begin{tabular}{rrrrr}
-- & 117 & 2,210 & 1,430 & 3,757 \\
-- & -- & 339 & 1,362 & 1,701 \\
-- & 91 & -- & 659 & 750 \\
-- & -- & -- & -- & -- \\
\hline-- & 208 & 2,549 & 3,451 & 6,208 \\
\hline
\end{tabular}

\begin{tabular}{lllll}
25 & -- & 42 & -- & 67 \\
-- & -- & -- & -- & -- \\
-- & -- & -- & -- & - \\
-- & -- & -- & -- & -- \\
\hline 25 & -- & 42 & -- & 67 \\
\hline
\end{tabular}

\begin{tabular}{rrrrr}
-- & 65 & 1,390 & 1,627 & 3,082 \\
-- & -- & -- & -- & -- \\
-- & -- & -- & 654 & 654 \\
-- & -- & -- & 234 & 234 \\
\hline-- & 65 & 1,390 & 2,515 & 3,970 \\
\hline
\end{tabular}


Table 6. (con.)

Forest type and

Productivity class

stand-size class

\begin{tabular}{llll}
\multicolumn{4}{c}{ Productivity } \\
\hline $120+$ & $85-119$ & $50-84$ & $20-49$
\end{tabular}

Tota]

acres

Engelmann spruce:

Sawtimber

Poletimber

Sapling and seedling

Nons tocked

Tota 1

Pinyon-juniper:

Sawtimber

Poletimber

Sapling and seedling

Nons tocked

Tota1

Aspen:

Sawtimber

Poletimber

Sapling and seedling

Nons tocked

Tota 1

Cottonwood:

Sawtimber

Poletimber

Sapling and seedling

Nons tocked

Tota 1

Mixed hardwoods:

Sawtimber

Poletimber

Sapling and seedling Nons tocked

Tota1

\begin{tabular}{rrrrr}
-- & 92 & 2,560 & 427 & 3,079 \\
-- & 196 & 1,251 & 411 & 1,858 \\
-- & -- & 831 & 3,413 & 4,244 \\
-- & -- & -- & -- & -- \\
\hline-- & 288 & 4,642 & 4,251 & 9,181 \\
\hline
\end{tabular}

\begin{tabular}{rrrrr}
-- & 110 & -- & 123 & 233 \\
-- & -- & 94 & 37 & 131 \\
-- & -- & -- & -- & -- \\
-- & -- & -- & 6 & 6 \\
\hline-- & 110 & 94 & 166 & 370 \\
\hline
\end{tabular}

\begin{tabular}{lllll}
-- & -- & -- & -- & -- \\
-- & -- & -- & -- & -- \\
-- & -- & -- & -- & -- \\
-- & -- & -- & -- & -- \\
\hline & & -- & -- & -- \\
\hline
\end{tabular}

A11 types:

Sawtimber

Poletimber

Sapling and seedling

Nons tocked

\begin{tabular}{rrrrr}
-- & -- & -- & 854 & 854 \\
-- & -- & -- & 276 & 276 \\
-- & -- & -- & 1,093 & 1,093 \\
-- & -- & -- & 263 & 263 \\
\hline-- & -- & - & 2,486 & 2,486 \\
\hline
\end{tabular}

\section{Total}

\begin{tabular}{rrrrr}
25 & 2,041 & 14,500 & 40,278 & 56,844 \\
-- & 201 & 3,909 & 15,320 & 19,430 \\
-- & 91 & 2,412 & 10,053 & 12,556 \\
-- & -- & -- & 4,156 & 4,156 \\
\hline 25 & 2,333 & 20,821 & 69,807 & 92,986 \\
\hline
\end{tabular}


Table 7.--Area of privately owned commercial timberland in New Mexico by forest type, stand-size class, and productivity class, 1980

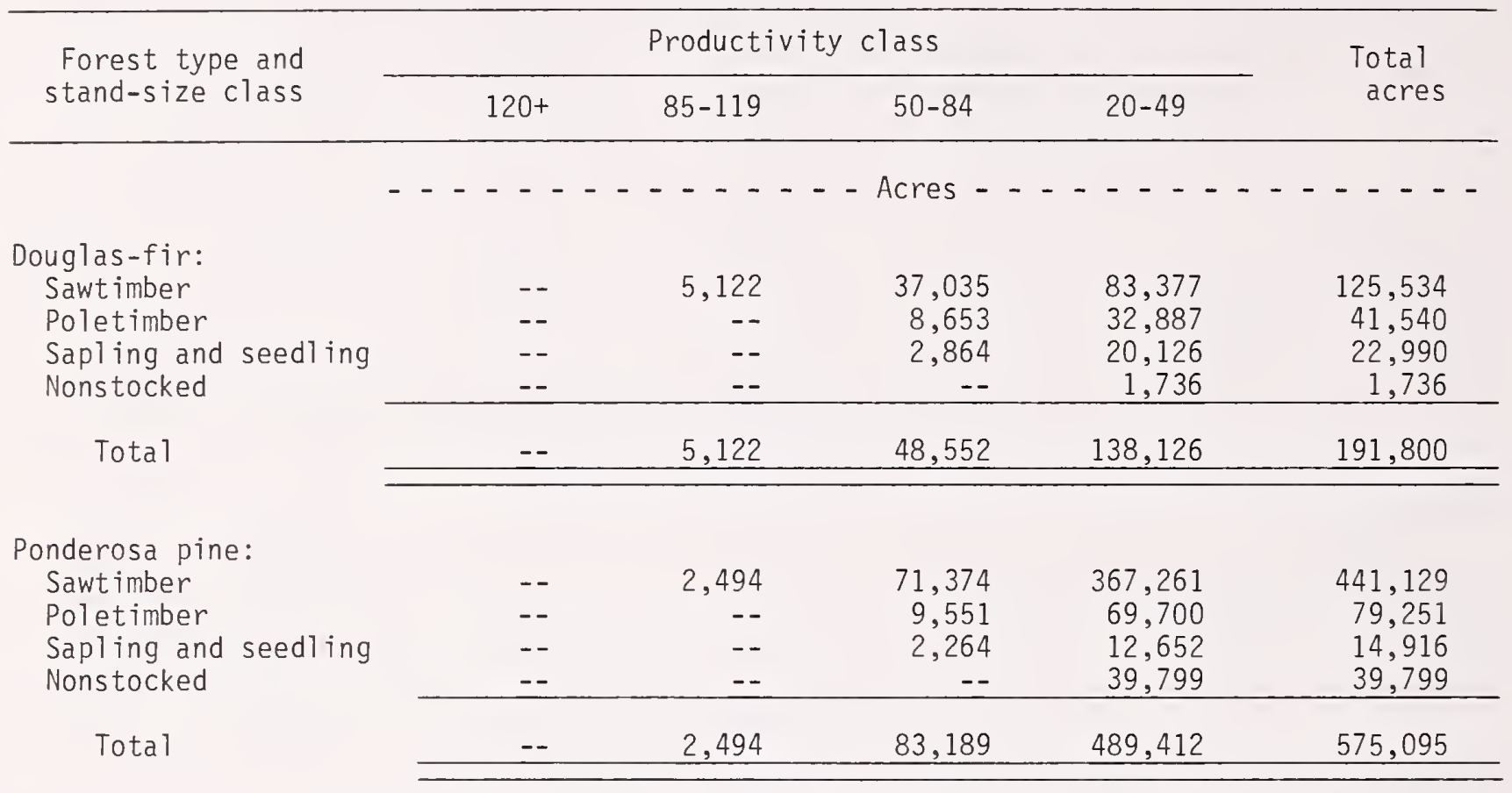

Southwestern white pine:

Sawtimber

Poletimber

Sapling and seedling

Nons tocked

Total

\begin{tabular}{rrrrr}
-- & -- & 664 & -- & 664 \\
-- & -- & -- & -- & -- \\
-- & -- & -- & -- & -- \\
-- & -- & -- & -- & 664 \\
\hline- & -- & 664 & -- & 664 \\
\hline
\end{tabular}

Spruce-subalpine fir:

Sawtimber

Poletimber

Sapling and seedling

Nonstocked

Total

\begin{tabular}{rrrrr}
-- & 5,458 & 53,737 & 39,409 & 98,604 \\
-- & -- & 9,988 & 8,282 & 18,270 \\
-- & 1,715 & -- & 9,218 & 10,933 \\
-- & -- & -- & -- & -- \\
\hline-- & 7,173 & 63,725 & 56,909 & 127,807 \\
\hline
\end{tabular}

Limber pine:

Sawtimber

Poletimber

Sapling and seedling

Nonstocked

Total

\begin{tabular}{rrrrr}
2,618 & -- & 1,113 & -- & 3,731 \\
-- & -- & -- & -- & -- \\
-- & -- & -- & -- & -- \\
-- & -- & -- & -- & 3,731 \\
\hline
\end{tabular}

White fir:

Sawtimber

Poletimber

Sapling and seedling

Nons tocked

\begin{tabular}{rrrrr}
-- & 4,611 & 21,986 & 14,277 & 40,874 \\
-- & -- & 644 & -- & 644 \\
-- & -- & -- & 2,856 & 2,856 \\
-- & 613 & 1,736 & 2,349 \\
\hline-- & 4,611 & 23,243 & 18,869 & 46,723 \\
\hline
\end{tabular}

Tota 1 
Table 7 (con.)

Forest type and

stand-size class

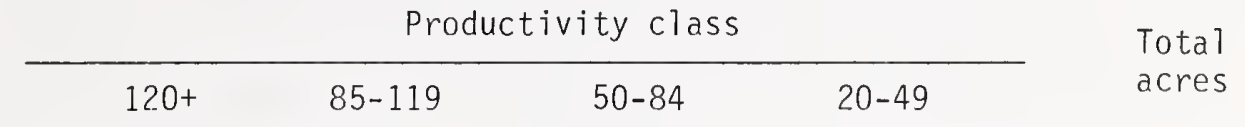

Engelmann spruce:

Sawtimber

Poletimber

Sapling and seedling

Nons tocked

Total

\begin{tabular}{rrrrr}
-- & 5,872 & 9,030 & 7,772 & 22,674 \\
-- & 665 & 4,573 & 12,821 & 18,059 \\
-- & -- & 5,916 & 1,912 & 7,828 \\
-- & -- & -- & 655 & 655 \\
\hline-- & 6,537 & 19,519 & 23,160 & 49,216 \\
\hline
\end{tabular}

Pinyon-juniper:

Sawtimber

Poletimber

Sapling and seedling

Nonstocked

Total

\begin{tabular}{rrrrr}
-- & -- & 123 & 21,339 & 21,462 \\
-- & -- & -- & 10,077 & 10,077 \\
-- & -- & -- & 8,303 & 8,303 \\
-- & -- & -- & 8,991 & 8,991 \\
\hline-- & & 123 & 48,710 & 48,833 \\
\hline
\end{tabular}

Aspen:

Sawt imber

Poletimber

Sapling and seedling

Nonstocked

Total

Cottonwood:

Sawt imber

Poletimber

Sapling and seedling

Nons tocked

Total

\begin{tabular}{rrrrr}
-- & 2,732 & 37,841 & 12,692 & 53,265 \\
611 & 5,313 & 7,627 & 8,104 & 21,655 \\
-- & -- & 8,835 & 26,730 & 35,565 \\
-- & -- & -- & -- & -- \\
\hline 611 & 8,045 & 54,303 & 47,526 & 110,485 \\
\hline & & & & \\
\hline-- & 1,521 & -- & 2,859 & 4,380 \\
-- & -- & 1,788 & 692 & 2,480 \\
-- & -- & -- & -- & -- \\
-- & -- & -- & 655 & 655 \\
\hline-- & 1,521 & 1,788 & 4,206 & 7,515 \\
\hline- & & & & 103 \\
\hline-- & -- & -- & -- & -- \\
\hline-- & -- & -- & -- & -- \\
\hline-- & -- & -- & 103 & 103 \\
\hline-- & -- & - & & \\
\hline
\end{tabular}

A11 types:

Sawtimber

Poletimber

Sapling and seedling

Nons tocked

\begin{tabular}{rrrrr}
2,618 & 27,810 & 232,903 & 549,089 & 812,420 \\
611 & 5,978 & 42,824 & 142,563 & 191,976 \\
-- & 1,715 & 19,879 & 81,797 & 103,391 \\
-- & -- & 613 & 53,572 & 54,185 \\
\hline 3,229 & 35,503 & 296,219 & 827,021 & $1,161,972$ \\
\hline
\end{tabular}




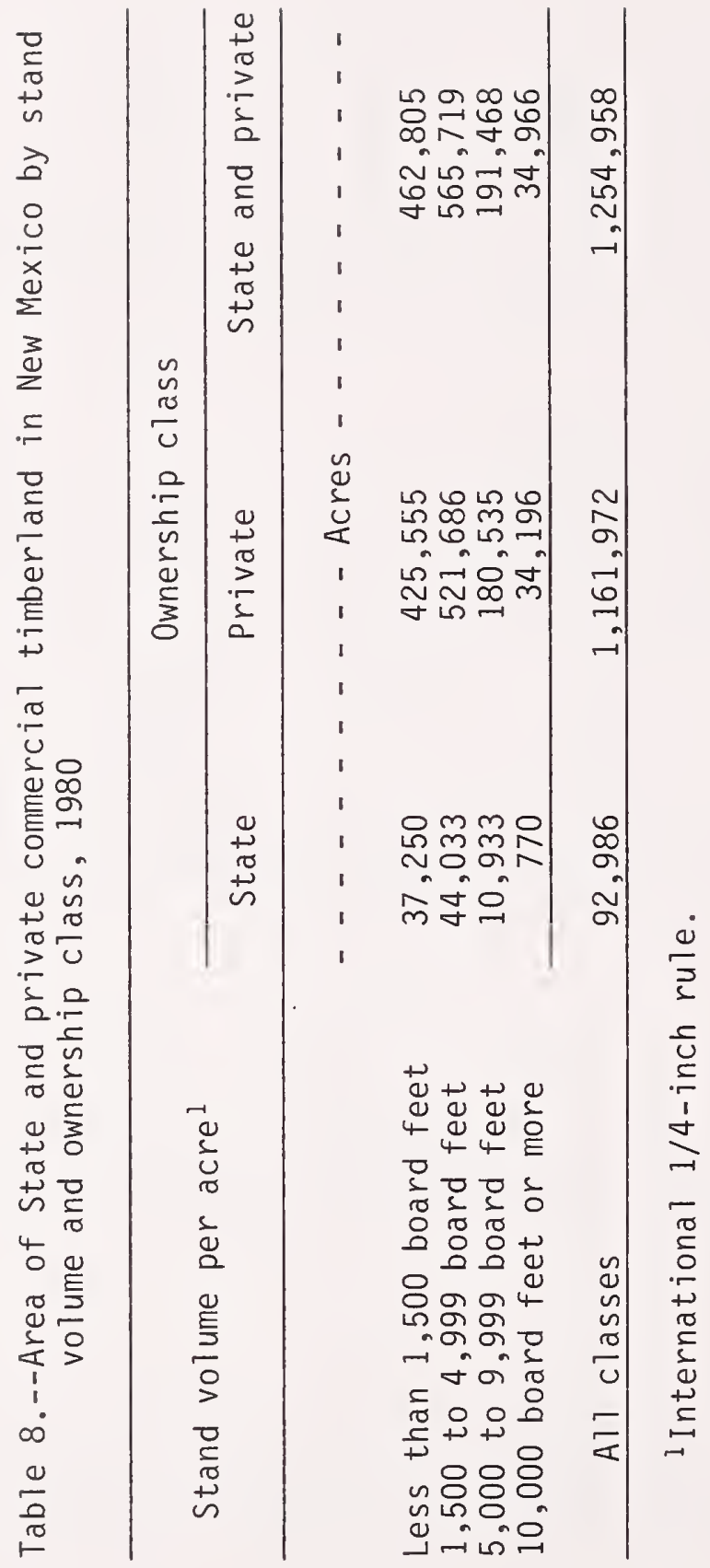




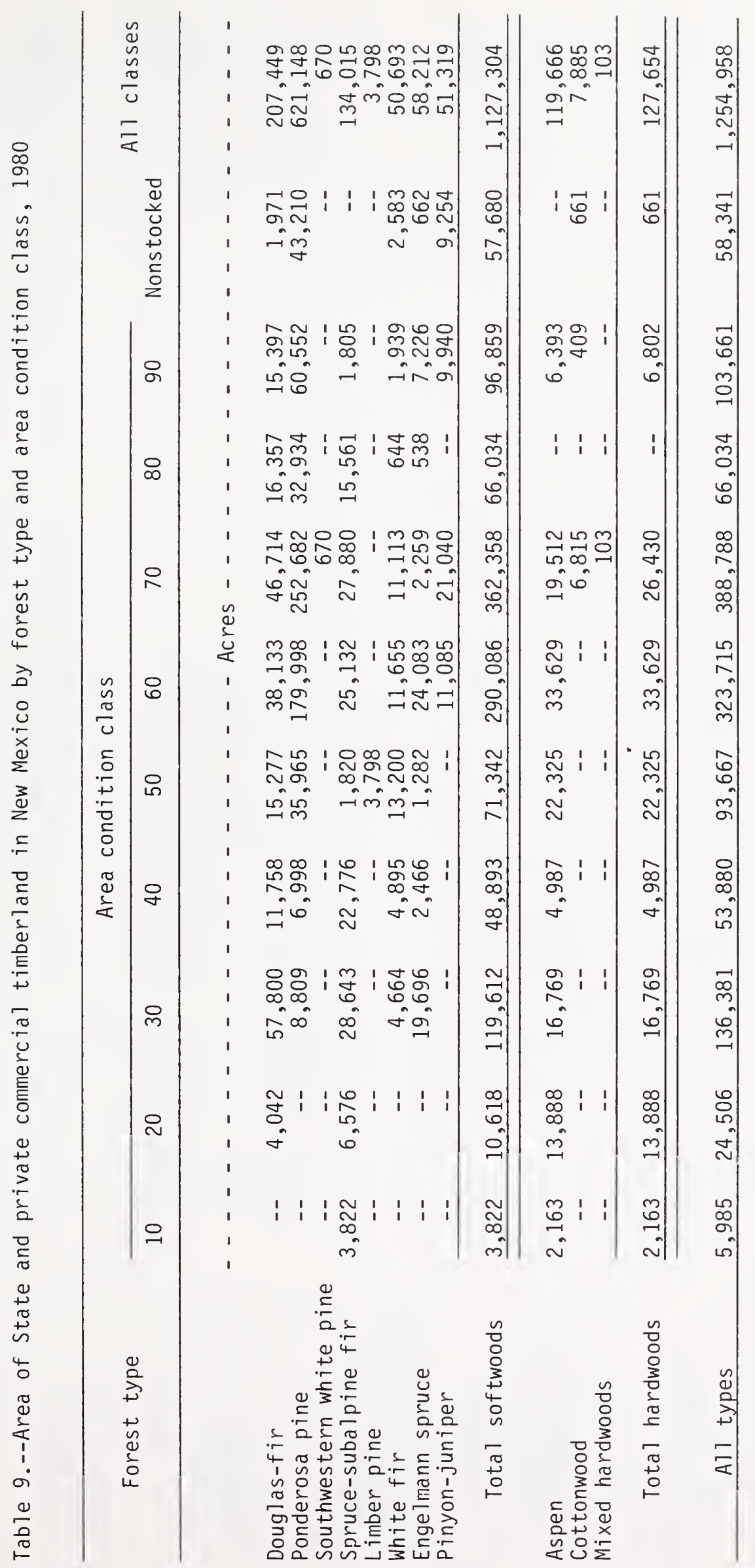




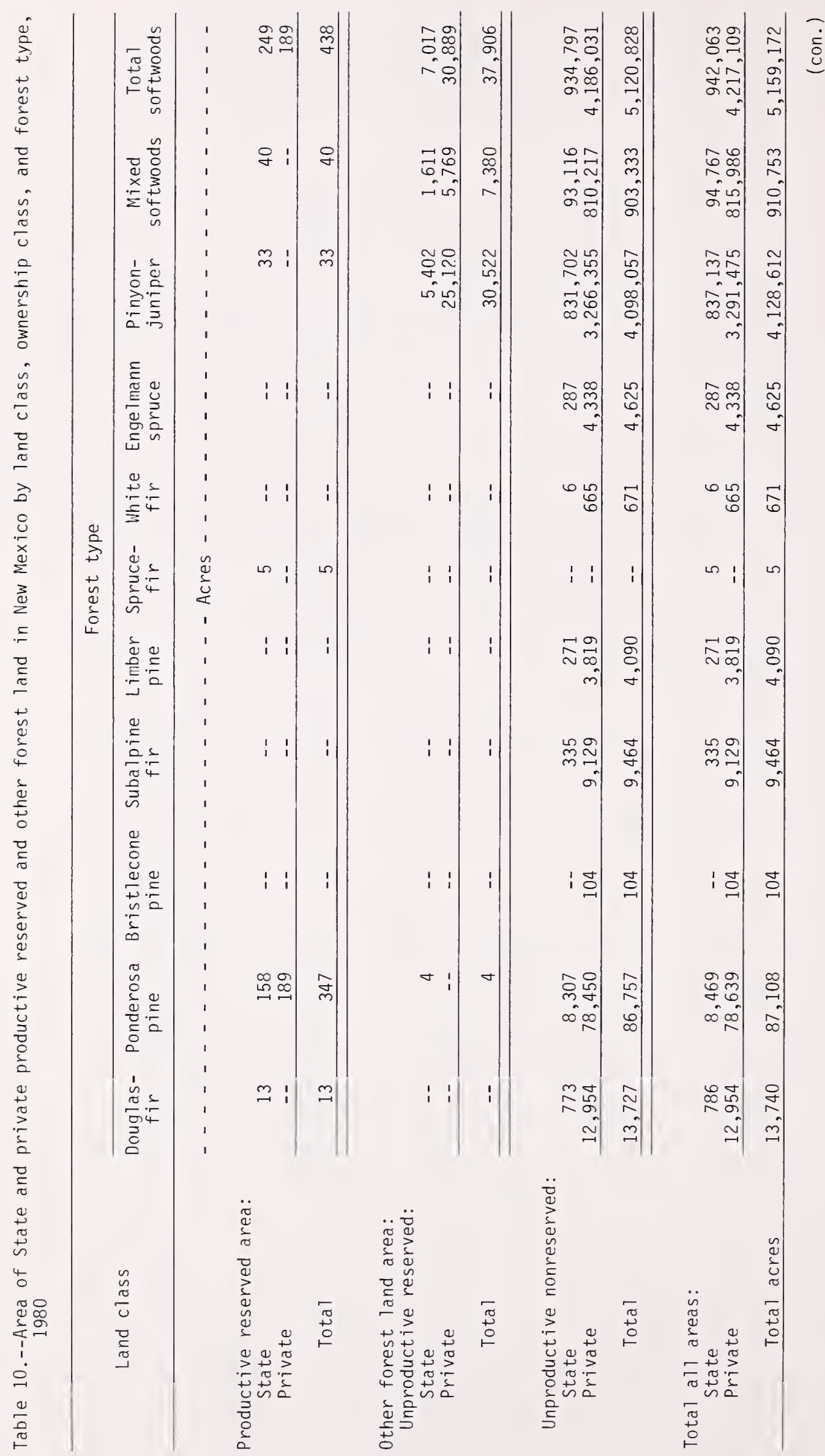




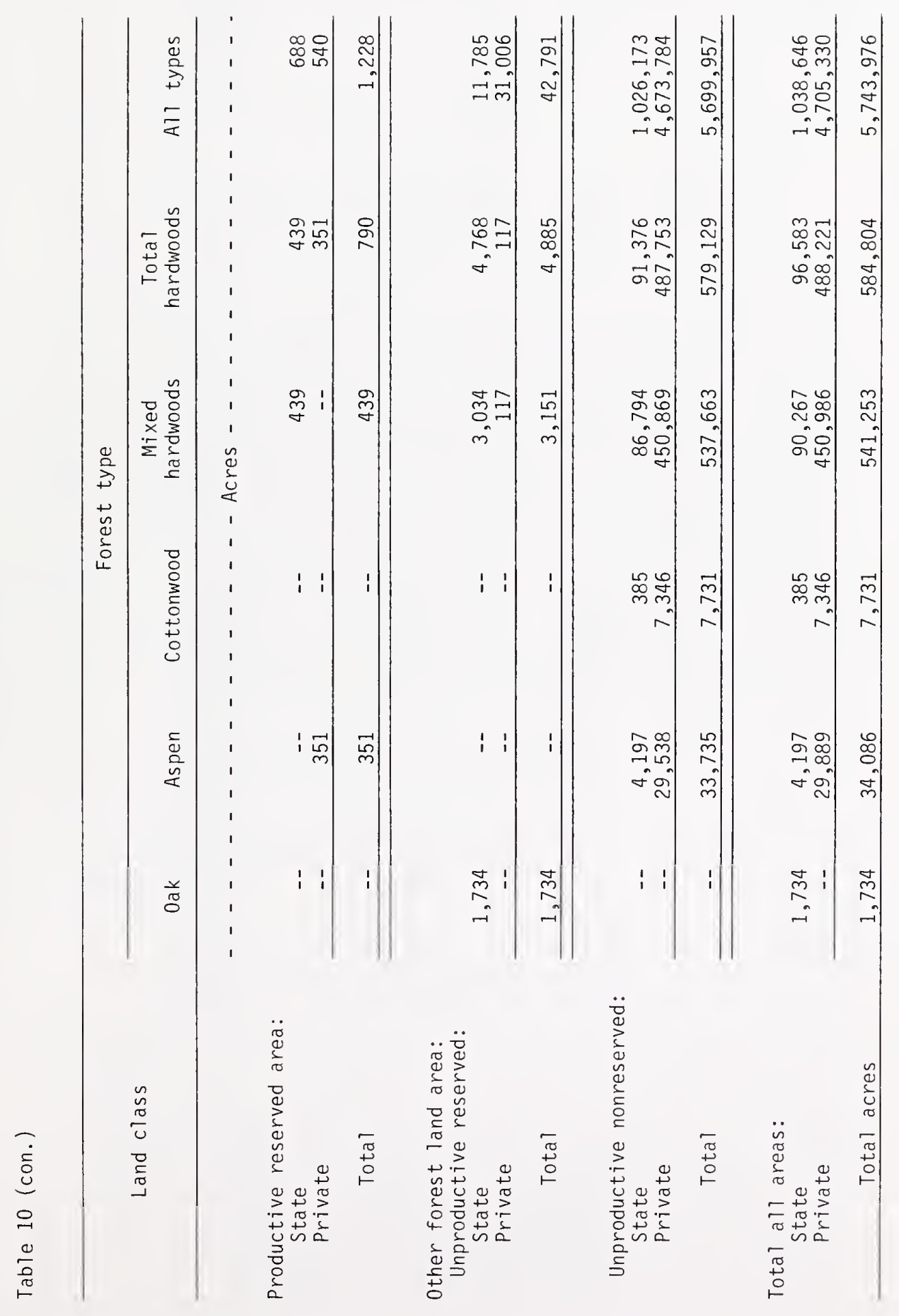




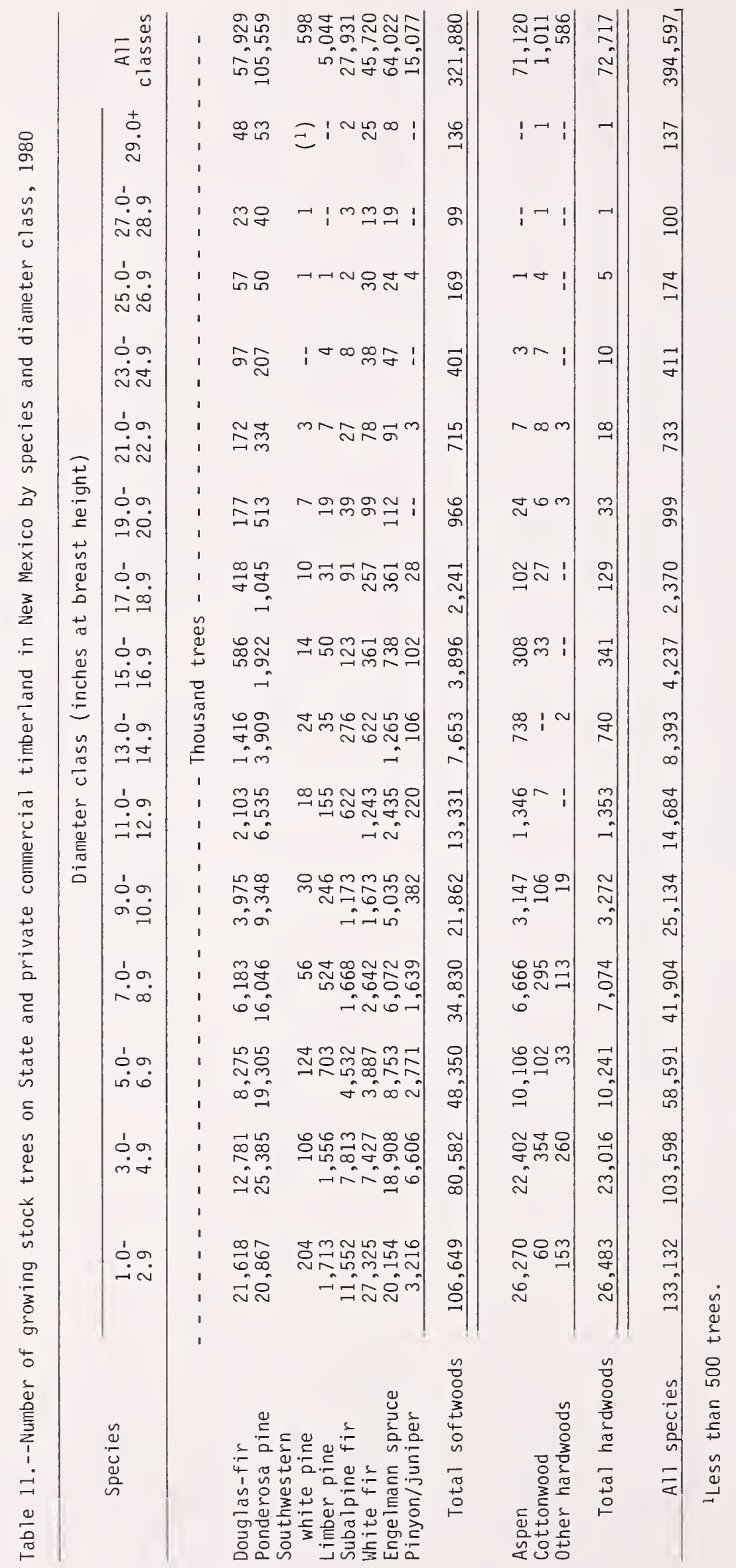




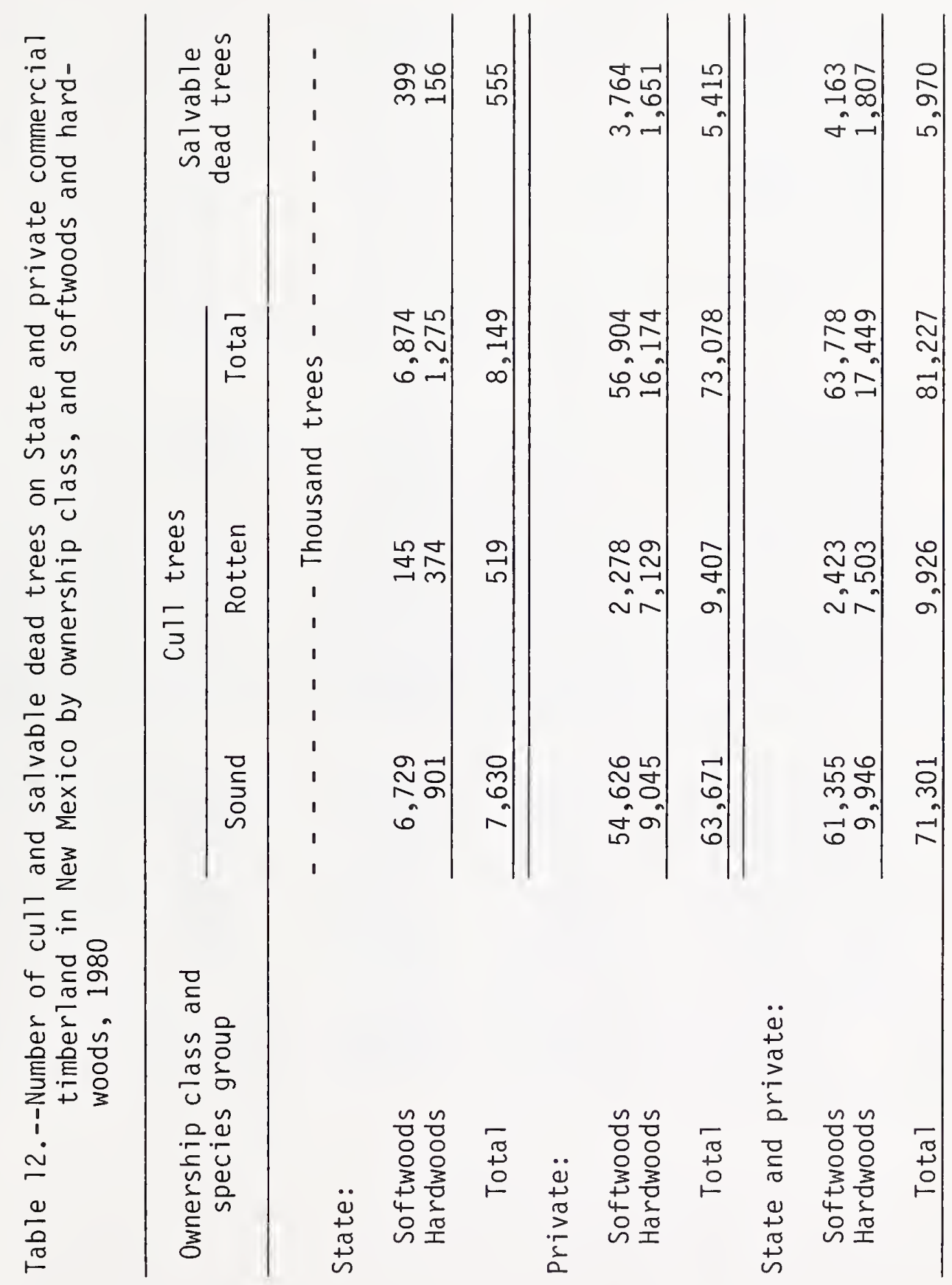


Table 13.--Net volume of growing stock on State and private commercial timberland in New Mexico by ownership class, forest type, and stand-size class, 1980

Stand-size class

Sawtimber Poletimber Sapling/seedling Nonstocked

A11 classes

_. . . . . . . . . . . Thousand cubic feet _ . . . . . . .

State:

Douglas-fir
Ponderosa pine
Southwestern white pine
Spruce-subalpine fir
Limber pine
White fir
Engelmann spruce
Pinyon-juniper
Aspen
Cottonwood
Mixed hardwoods

\begin{tabular}{|c|c|c|c|c|}
\hline $\begin{array}{r}6,177 \\
26,159\end{array}$ & $\begin{array}{l}3,502 \\
3,385\end{array}$ & $\begin{array}{r}1,022 \\
106\end{array}$ & $\begin{array}{r}46 \\
607\end{array}$ & $\begin{array}{l}10,747 \\
30,257\end{array}$ \\
\hline & & -- & -- & 6 \\
\hline 7,113 & 1,822 & 233 & -- & 9,168 \\
\hline 134 & -- & - & - & 134 \\
\hline 3,322 & -- & 191 & 50 & 3,563 \\
\hline 6,491 & 3,487 & 959 & (1) & 10,937 \\
\hline 208 & & 69 & 13 & 354 \\
\hline 4,059 & 4,638 & 958 & -- & 9,655 \\
\hline 289 & 101 & -- & 2 & 392 \\
\hline-- & -- & -- & -- & -- \\
\hline 53,958 & 16,999 & 3,538 & 718 & 75,213 \\
\hline
\end{tabular}

Private:

\section{A11 types}

Douglas-fir
Ponderosa pine
Southwestern white pine
Spruce-subalpine fir
Limber pine
White fir
Engelmann spruce
Pinyon-juniper
Aspen
Cottonwood
Mixed hardwoods

A11 types

State and private:

Douglas-fir
Ponderosa pine
Southwestern white pine
Spruce-subalpine fir
Limber pine
White fir
Engelmann spruce
Pinyon-juniper
Aspen
Cottonwood
Mixed hardwoods

\begin{tabular}{rrrrr}
175,938 & 31,558 & 7,652 & 343 & 215,491 \\
332,085 & 40,658 & 2,708 & 6,609 & 382,060 \\
735 & -- & -- & -- & 735 \\
162,138 & 20,829 & 3,161 & -- & 186,128 \\
8,549 & -- & -- & -- & 8,549 \\
53,021 & 526 & 835 & 624 & 55,006 \\
35,224 & 22,831 & 5,313 & 58 & 63,426 \\
6,119 & 2,417 & 741 & 452 & 9,729 \\
97,834 & 40,189 & 9,612 & -- & 147,635 \\
5,165 & 1,921 & -- & 189 & 7,275 \\
20 & -- & -- & $-1,076,054$ \\
\hline
\end{tabular}

$$
\text { A11 types }
$$

\begin{tabular}{rrrrr}
182,115 & 35,060 & 8,674 & 389 & 226,238 \\
358,244 & 44,043 & 2,814 & 7,216 & 412,317 \\
741 & -- & -- & -- & 741 \\
169,251 & 22,651 & 3,394 & -- & 195,296 \\
8,683 & -- & -- & -- & 8,683 \\
56,343 & 526 & 1,026 & 674 & 58,569 \\
41,715 & 26,318 & 6,272 & 58 & 74,363 \\
6,327 & 2,481 & 810 & 465 & 10,083 \\
101,893 & 44,827 & 10,570 & -- & 157,290 \\
5,454 & 2,022 & -- & 191 & 7,667 \\
20 & -- & -- & -- & 20 \\
\hline 930,786 & 177,928 & 33,560 & 8,993 & $1,151,267$ \\
\hline
\end{tabular}

\footnotetext{
${ }^{1}$ Less than 0.5 thousand cubic feet.
} 
Table 14.--Net volume of sawtimber on State and private commercial timberland in New Mexico by ownership class, forest type, and stand-size class, 1980

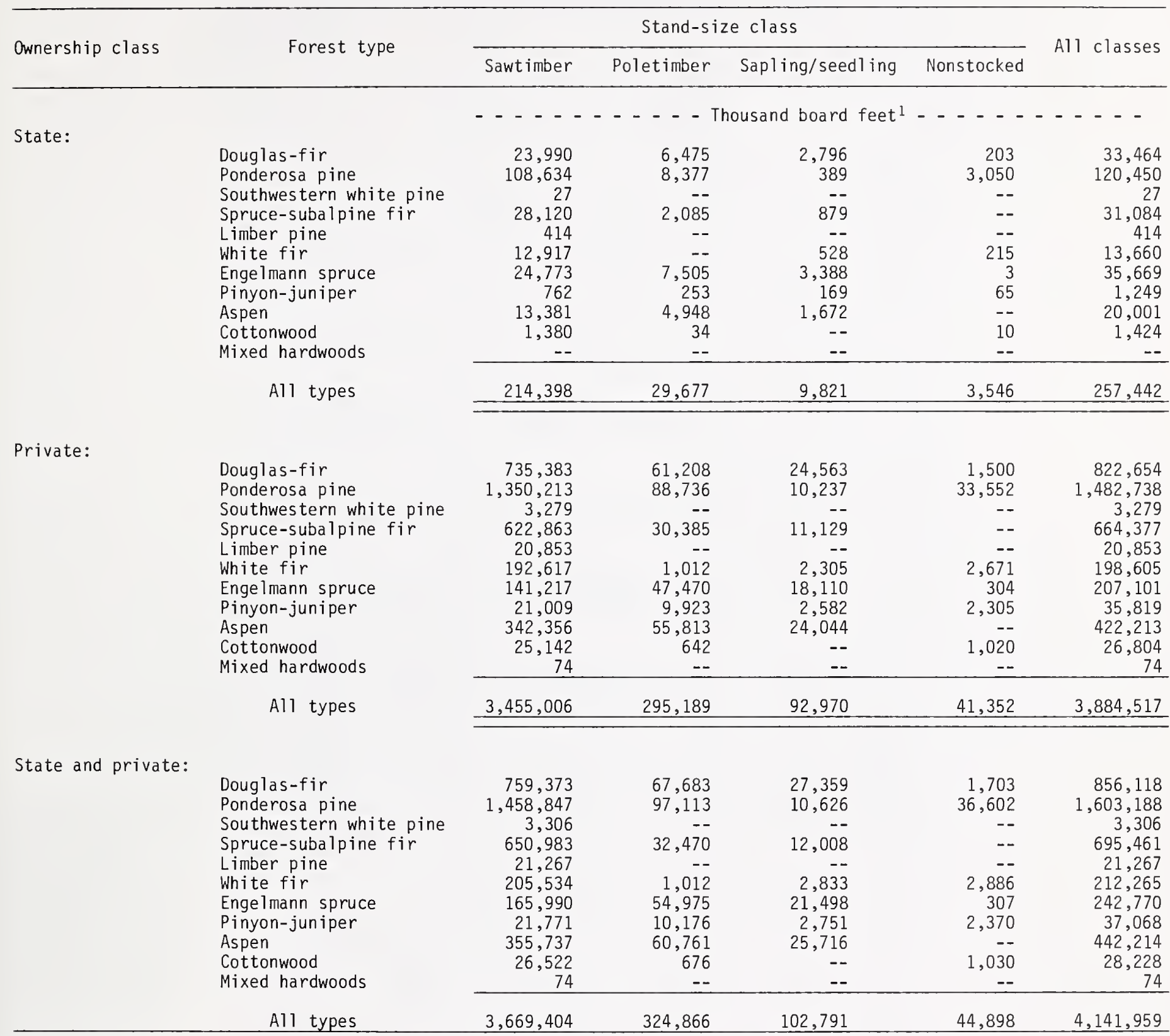

International $1 / 4-$ inch rule. 


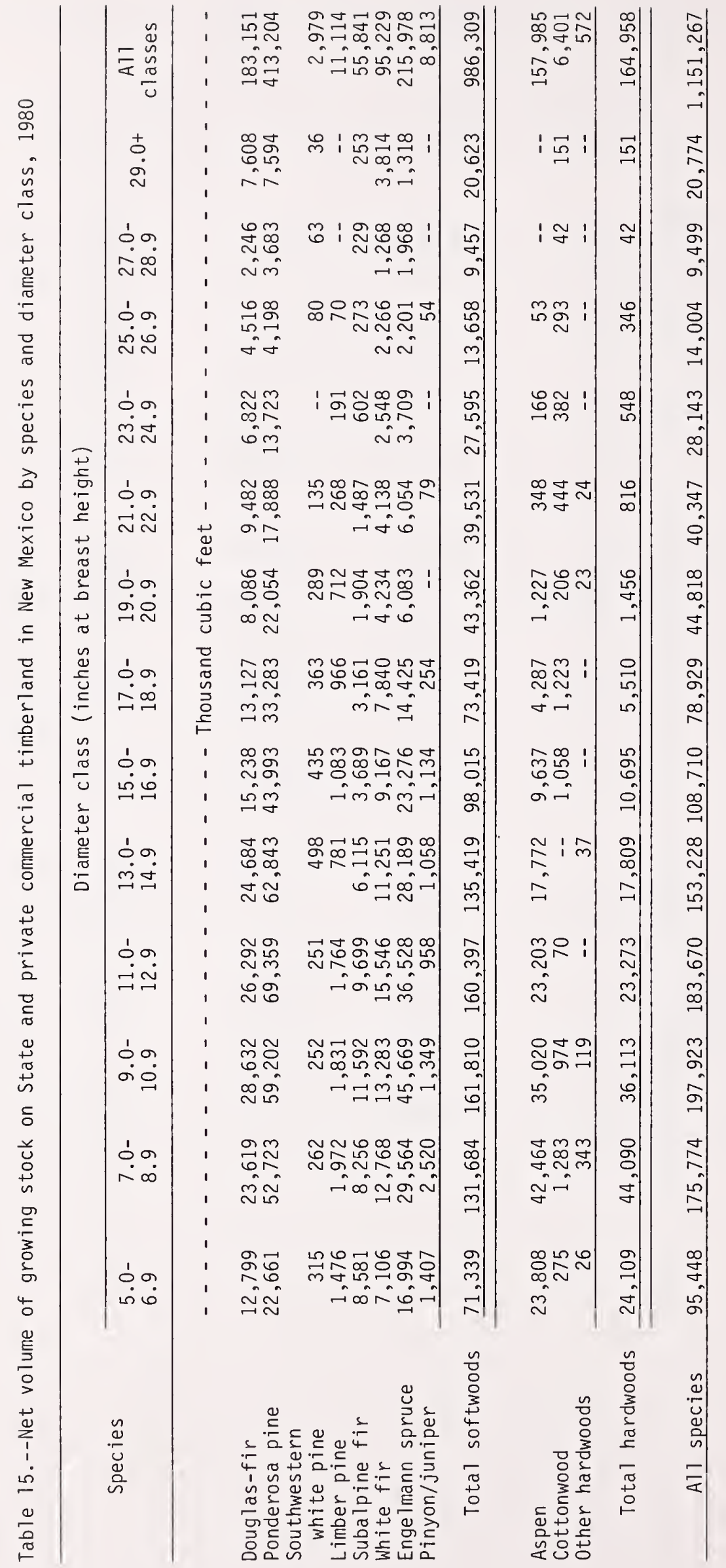




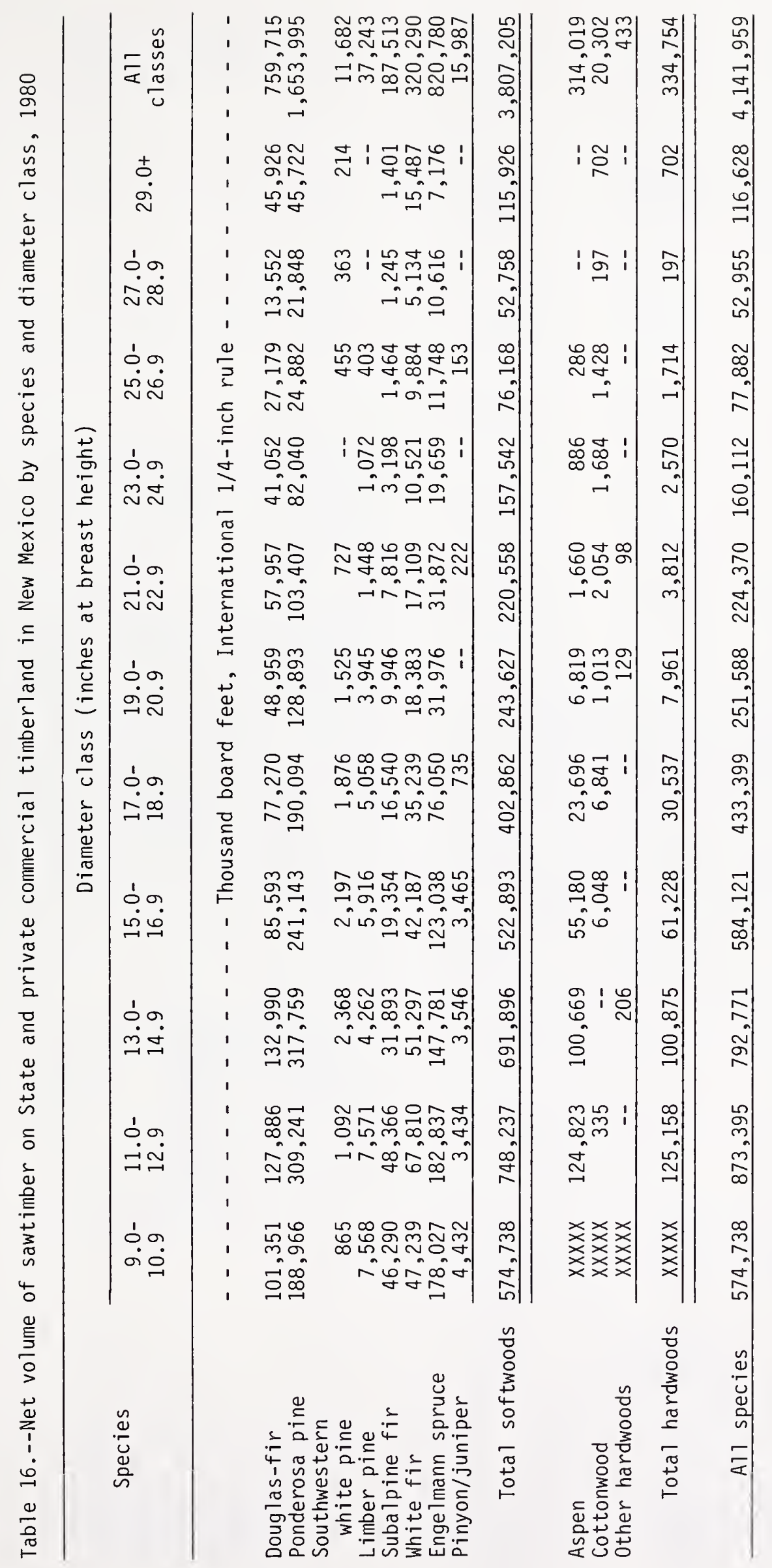




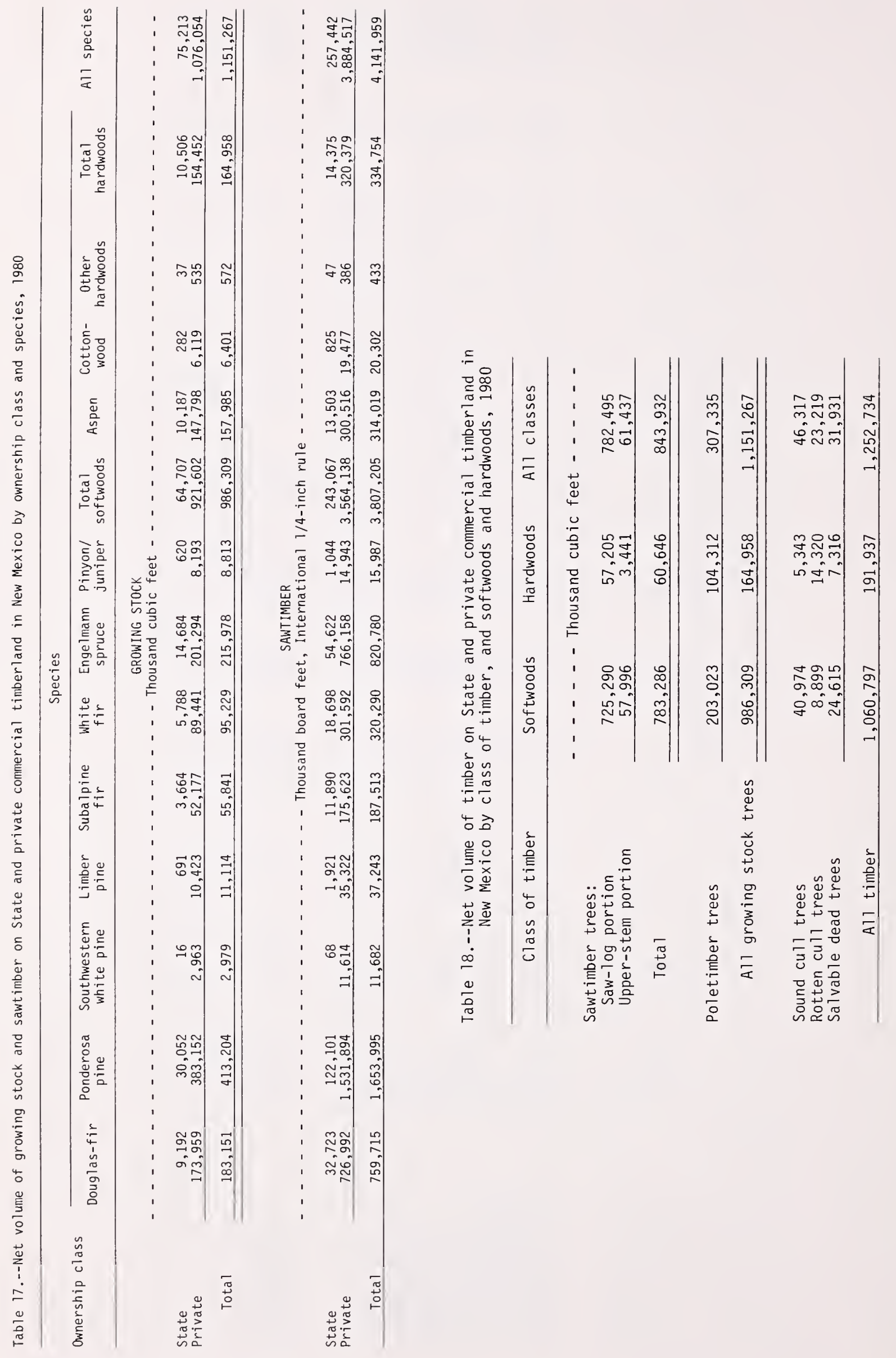



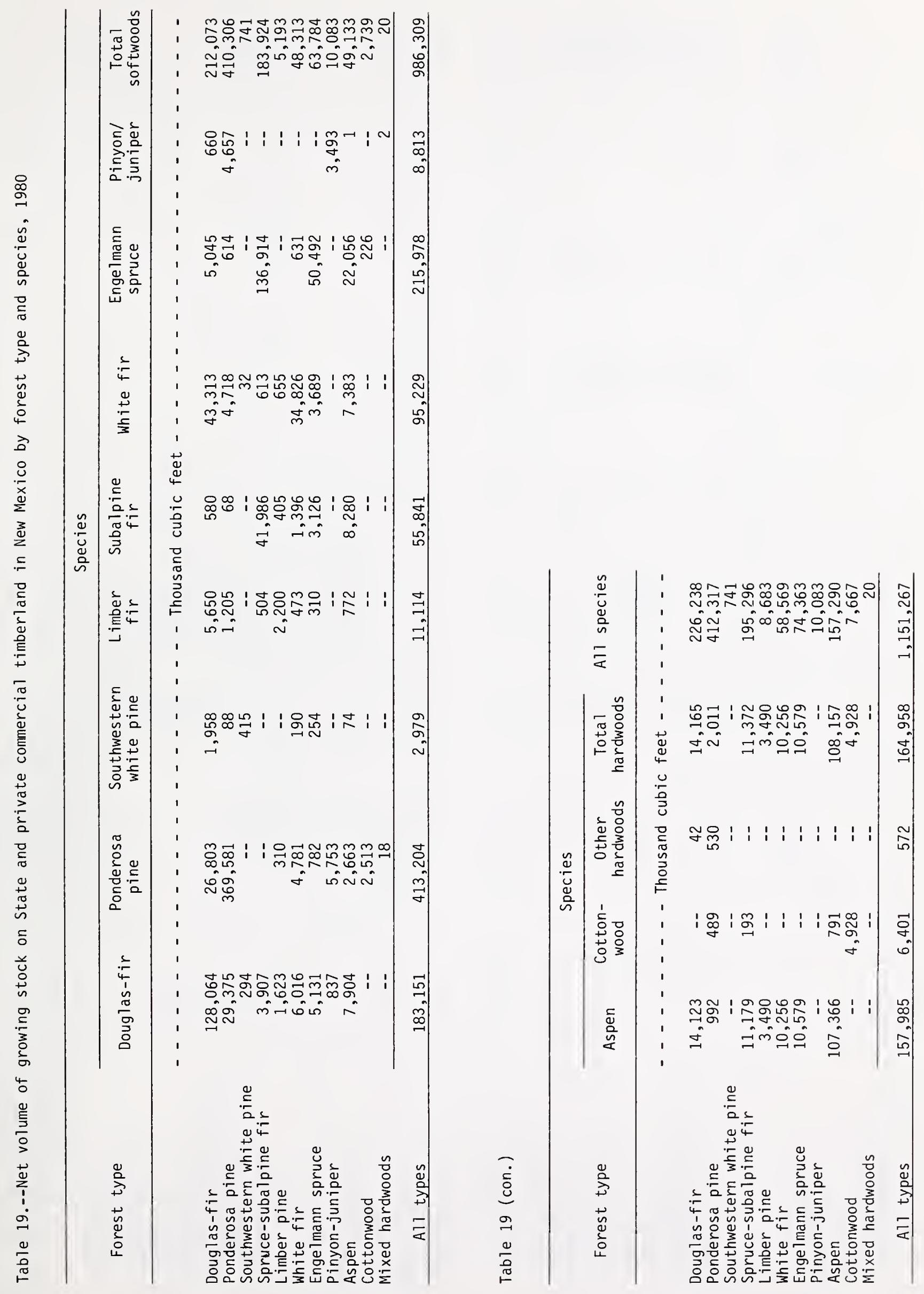

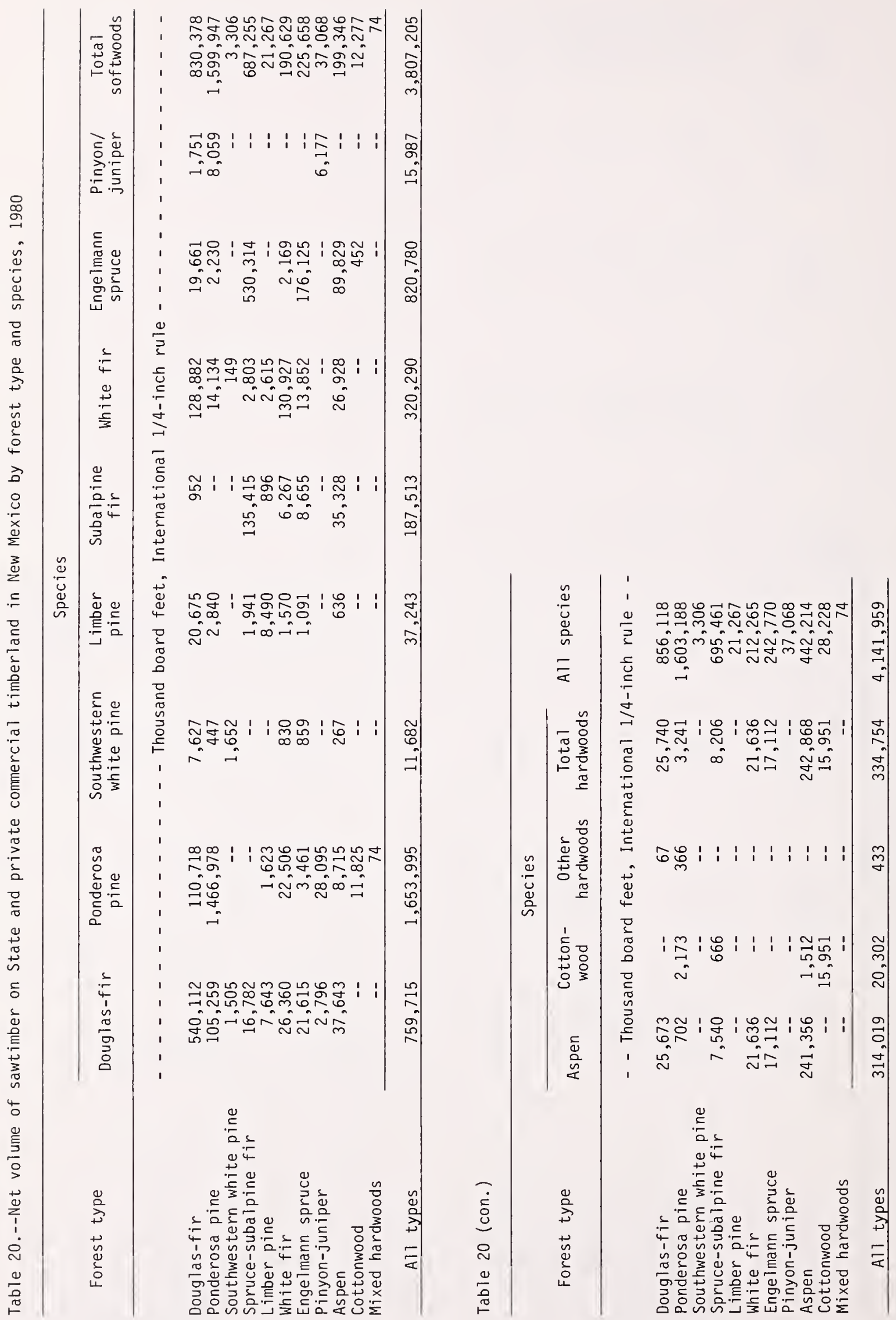


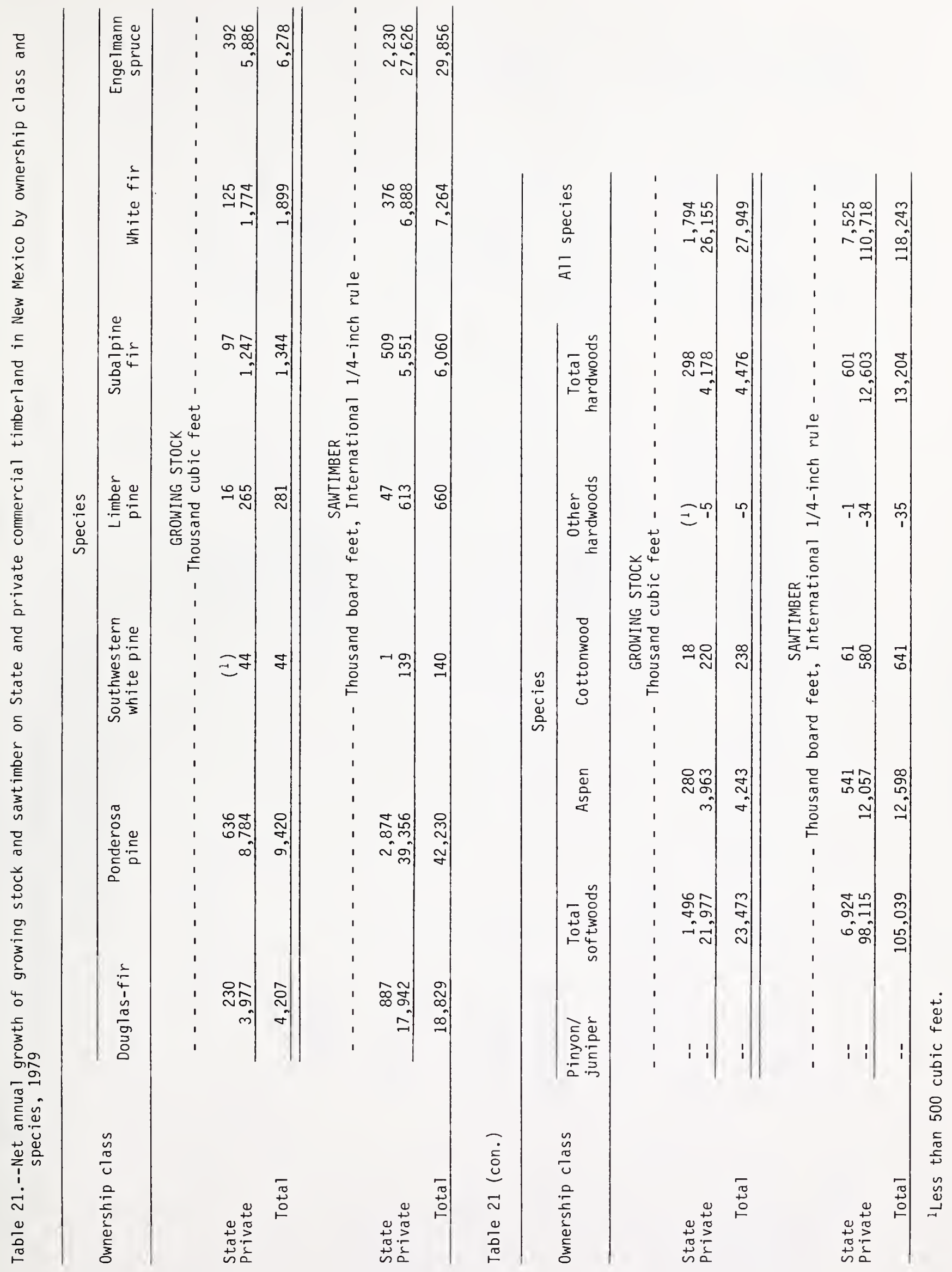




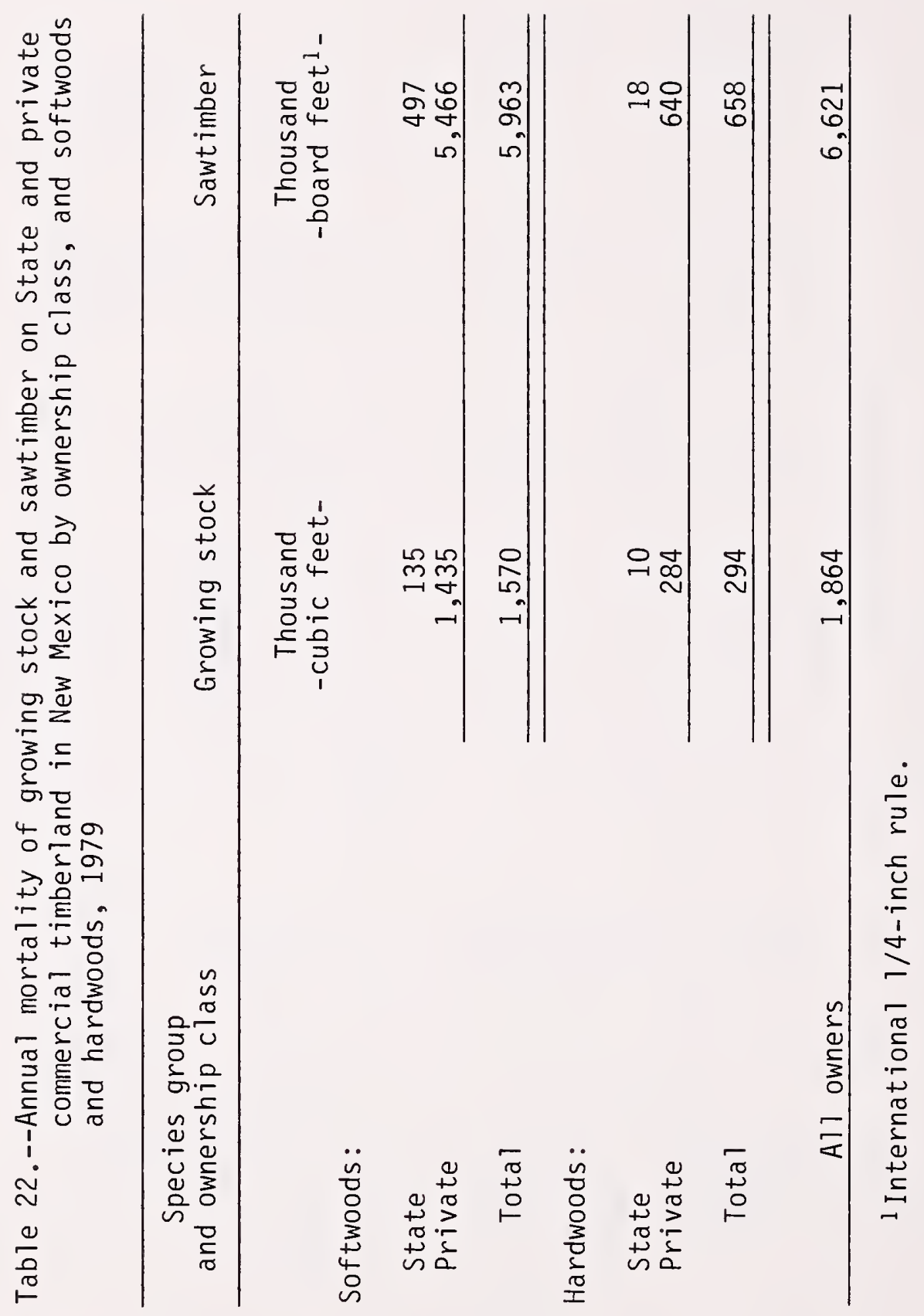




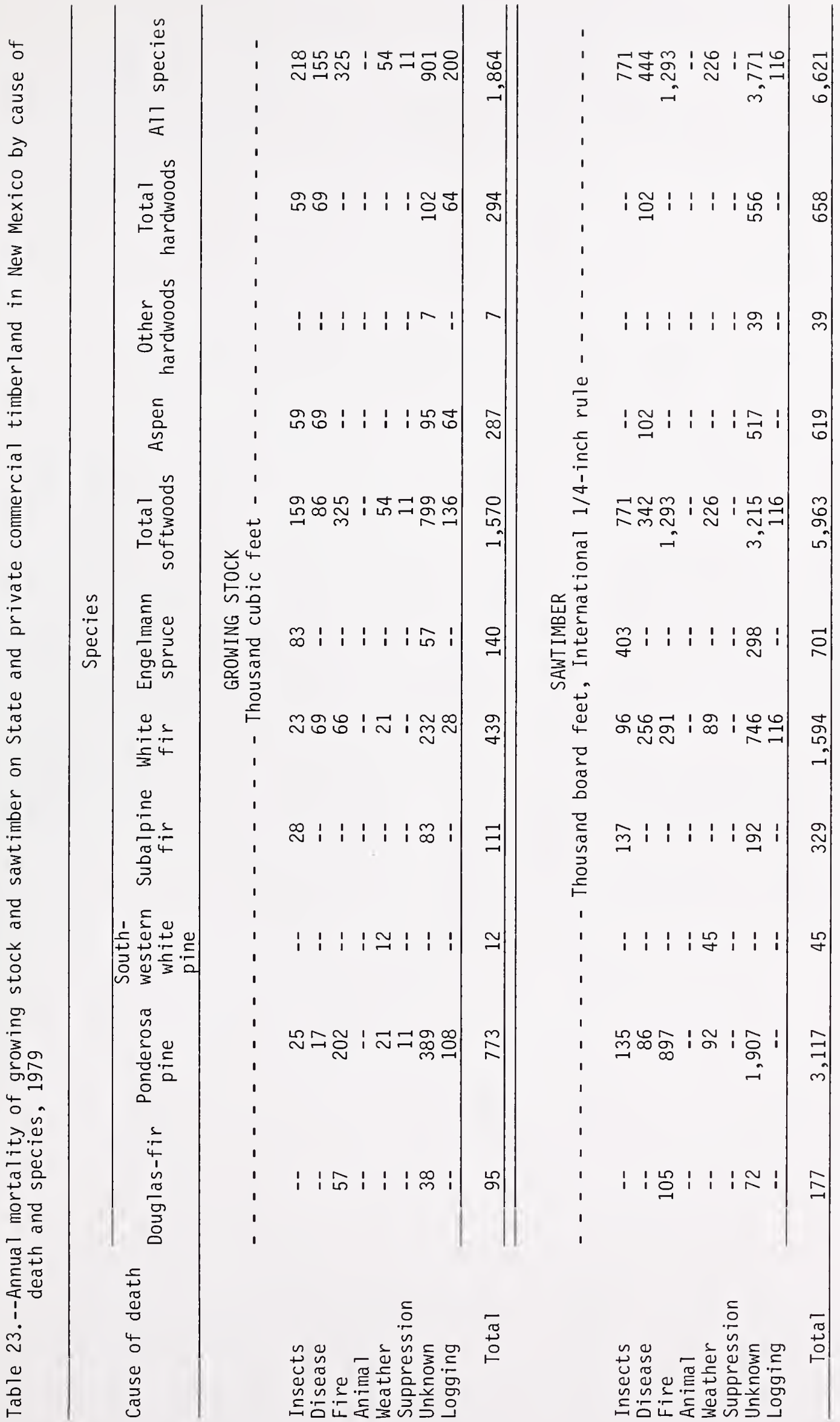



Felt, Dorothy G.; Sterrett, Velma J. Forest area and timber resource statistics for State and private lands in New Mexico, 1980. Resourc. Bull. INT-32. Ogden, UT: U.S. Department of Agriculture, Forest Service, Intermountain Forest and Range Experiment Station; 1983. 29p.

Presents land area, commercial timberland area, timber inventory, and growth and mortality data based on Forest Survey standards.

KEYWORDS: forest surveys (regional), forest area classification, stand volume 
The Intermountain Station, headquartered in Ogden, Utah, is one of eight regional experiment stations charged with providing scientific knowledge to help resource managers meet human needs and protect forest and range ecosystems.

The Intermountain Station includes the States of Montana, Idaho, Utah, Nevada, and western Wyoming. About 231 million acres, or 85 percent, of the land area in the Station territory are classified as forest and rangeland. These lands include grasslands, deserts, shrublands, alpine areas, and well-stocked forests. They supply fiber for forest industries; minerals for energy and industrial development; and water for domestic and industrial consumption. They also provide recreation opportunities for millions of visitors each year.

Field programs and research work units of the Station are maintained in:

Boise, Idaho

Bozeman, Montana (in cooperation with Montana State University)

Logan, Utah (in cooperation with Utah State University)

Missoula, Montana (in cooperation with the University of Montana)

Moscow, Idaho (in cooperation with the University of Idaho)

Provo, Utah (in cooperation with Brigham Young University)

Reno, Nevada (in cooperation with the University of Nevada)

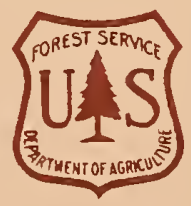

